\title{
EL CULTIVO DE STEVIA EN VERACRUZ: ¿UN PROYECTO DE DESARROLLO?
}

\section{STEVIA FARMING IN VERACRUZ: A DEVELOPMENT PROJECT?}

\author{
Virginie Thiébaut ${ }^{*}$ Ana Fontecilla -Carbonell
}

\author{
Instituto de Investigaciones Histórico-Sociales, Universidad Veracruzana. (virginiathiebaut@ \\ yahoo.fr) (afonteci@hotmail.com)
}

\begin{abstract}
RESUMEN
El programa "Prospera", política social mexicana de transferencias condicionadas, recientemente incluyó la estrategia de "inclusión productiva" como una forma de posibilitar a las beneficiarias la obtención de ingresos mediante proyectos productivos. En el caso de la región de Los Tuxtlas, esta iniciativa tomó forma en la promoción de huertos de stevia, una planta cuyos componentes tienen alto poder endulzante y grandes posibilidades de mercado, incluso a nivel internacional, al ser considerados como endulzantes naturales no calóricos e inocuos para la salud humana. En este estudio, fundamentado en el análisis de los medios de vida de las familias de las beneficiarias del proyecto y el registro de las prácticas de cultivo, procesado y comercialización de la stevia, se observó cómo la rentabilidad del proyecto y sus beneficios sociales potenciales se desvirtuaron cuando fue manejado con fines político-electorales y se dejó de lado el seguimiento de las prácticas productivas.
\end{abstract}

Palabras clave: huertos de stevia, medios de vida, Programa Prospera, proyecto de desarrollo, uso electoral.

\section{INTRODUCCIÓN}

$\mathrm{E}$ $\mathrm{n}$ el contexto actual de retiro del apoyo estatal al campo, las políticas de transferencias condicionadas han sido determinantes para los sistemas de sustento de las familias campesinas. En este trabajo se examina una innovación reciente que se ha hecho a este tipo de políticas en la figura de "inclusión productiva" dentro de las reglas de operación de Prospera, la cual en el caso particular del estudio implicó la promoción de huertos de stevia entre las beneficiarias del programa en localidades aledañas a San Andrés Tuxtla, en el Estado de Veracruz, con el

* Autor responsable * Author for correspondence.

Recibido: octubre, 2015. Aprobado: agosto, 2016.

Publicado como ARTÍCULO en ASyD 14: 239-262. 2017.

\begin{abstract}
The "Prospera" program, Mexican social policy of conditioned transfers, recently included the strategy of "productive inclusion" as a way of making possible for beneficiaries to obtain income through productive projects. In the case of the region of Los Tuxtlas, this initiative took shape in the promotion of stevia plantations, a plant whose components have a high sweetening power and great market possibilities, even at the international level, since it is considered as a natural non-caloric and innocuous sweetener for human health. In this study, based on the analysis of the livelihoods of the families of the project's beneficiaries and the registry of cultivation, processing and commercialization practices of stevia, the profitability of the project was observed and its potential social benefits were misinterpreted when it was handled for political-electoral aims, and the follow-up of productive practices were put aside.
\end{abstract}

Key words: stevia plantations, livelihoods, Prospera Program, development project, electoral use.

\section{INTRODUCTION}

W ithin the current context of the withdrawal of state support for the countryside, the policies of conditioned transfers have been decisive for the sustenance systems of peasant families. In this study a recent innovation is examined that was made to this type of policies in the figure of "productive inclusion" within Prospera's operation rules, which in the particular case of the study implied the promotion of stevia plantations among beneficiaries of the program in localities neighboring San Andrés Tuxtla, in the state of Veracruz, with the declared purpose of allowing them to obtain additional income. This proposal is particularly interesting since, in comparison to other productive projects commonly destined to the social sector, stevia is profiled as a product with 
propósito declarado de permitirles obtener ingresos adicionales. Esta propuesta resulta particularmente interesante ya que, a diferencia de otros proyectos productivos comúnmente destinados al sector social, la stevia se perfilaba como un producto con prometedor potencial de mercado, tanto a nivel nacional como internacional. Este se basa en el interés que importantes compañías transnacionales han puesto en el desarrollo y promoción de este endulzante -motivado por su carácter natural, bajo aporte energético, inocuidad y propiedades medicinales que se le han atribuido a sus extractos- y en el consecuente crecimiento exponencial de sus ventas a nivel mundial.

El propósito de este trabajo se basó en la evaluación de la factibilidad y rentabilidad del proyecto y sus posibles efectos sociales, y se dedicó también conforme iba avanzando la investigación- a analizar e interpretar las incongruencias que se evidenciaron al estudiar la dinámica del proyecto en el tiempo. Con este fin el texto se ha organizado en tres apartados. En el primero se expone la situación actual del mercado mundial de endulzantes, con el fin de comprender las cualidades y el potencial que tiene la stevia; se relata además cómo su cultivo fue introducido en la región y adoptado por el programa Prospera. En el segundo apartado se describen las condiciones, medios y estrategias de vida de los hogares en las localidades de estudio, así como los cambios y aportaciones que el cultivo de stevia representó en el conjunto de ingresos y organización laboral de las familias beneficiarias y en el territorio. Finalmente, en el tercer apartado se explica cómo la rentabilidad y los beneficios sociales del proyecto se fueron diluyendo por las diversas negligencias e incongruencias en que incurrieron los promotores a lo largo del proceso cuando los fines político-electorales parecieron ser más importantes que los objetivos del mismo.

\section{Metodología y Sustentos}

Este trabajo de investigación se realizó mediante recorridos de campo durante los cuales se observaron y estudiaron los cambios socio-territoriales en la región de San Andrés Tuxtla debidos al rápido desarrollo del cultivo de la stevia. Se realizaron en paralelo entrevistas semi estructuradas a 38 productores en seis comunidades (Comoapan, Bezuapan, Salto de Eyipantla, Santa Rosa Abata, Matacapan, Caleria) para entender los inicios, la dinámica de desarrollo y promising market potential, both at the national and international level. It is based on the interest that important transnational companies have placed on the development and promotion of this sweetener - motivated by its natural character, low energetic contribution, innocuousness, and the medicinal properties that have been attributed to its extracts and in the resulting exponential growth of its sales at the global level.

The purpose of this study was based on the evaluation of the feasibility and profitability of the project and its possible social effects, and is also devoted - as the research advanced - to analyzing and interpreting the contradictions that were evidenced when studying the dynamics of the project in time. With this objective, the text has been organized into three sections. In the first one the current situation of the global sweetener market is exposed, with the aim of understanding the qualities and the potential of stevia; the way in which the crop was introduced into the region and adopted by the Prospera program is also described. In the second section the living conditions, means and livelihood strategies of the households in the localities of study are described, as well as the changes and contributions that the stevia crop represented in the sum of income and work organization of the beneficiary families and in the territory. Finally, the third section explains the way in which profitability and social benefits of the project were blurred by the various malpractices and contradictions in which the promoters were involved throughout the process, when the political-electoral aims seemed to be more important than their objectives.

\section{Methodology and Foundation}

This research work was carried out through field visits during which the socio-territorial changes in the San Andrés Tuxtla region due to the fast development of the stevia crop, were observed and studied. In parallel, semi-structured interviews were performed with 38 producers in six communities (Comoapan, Bezuapan, Salto de Eyipantla, Santa Rosa Abata, Matacapan, Caleria) to understand the beginning, the development dynamics, and the techniques of the new crop ${ }^{1}$. Informants of different ages were selected, vocals (representatives of the title holder women), and non-vocals of the Prospera 
las técnicas del nuevo cultivo ${ }^{1}$. Se seleccionó a informantes de distintas edades, vocales (representantes de las titulares) y no vocales del programa Prospera, con acceso o no a tierras ejidales, para obtener así los testimonios de una gama diversificada de productores. Predominaron las entrevistas a mujeres por la naturaleza del programa, dirigido a familias de bajos recursos, y cuyas titulares son, en general, las madres de familia ${ }^{2}$. Además de permitir entender la historia del cultivo, las entrevistas se enfocaron a analizar los medios y estrategias de vida de los hogares (Scoones, 1998). Gracias a este enfoque se pueden observar las interacciones entre políticas macroeconómicas, instituciones locales y procesos que ocurren al interior de los hogares e identificar y valorar "las capacidades, los activos (reservas, recursos, reclamos y acceso), las actividades y el acceso a estos (por medio de instituciones y relaciones sociales) que en conjunto determinan la forma de vida a la que puede acceder un individuo o un hogar" (Ellis, 2000). Los bienes o activos representan la plataforma para las estrategias de vida, donde el acceso a diferentes tipos de "capitales" (financiero, físico, natural, social y humano) provee determinadas capacidades a individuos y hogares para desarrollar sus estrategias (DFID, 1999) ${ }^{3}$. Estas entrevistas, y otras llevadas a cabo con los responsables del proyecto a distintos niveles (ingenieros de la empresa, delegado estatal de Prospera), permitieron evidenciar las numerosas incongruencias del proyecto, que solamente se pudieron explicar al establecer su vínculo con el proceso electoral acontecido en el estado de Veracruz en 2015. Como lo menciona Auyero (2011), los sistemas de relaciones en dónde se centra el análisis del clientelismo no se dejan ver fácilmente, por lo cual fue solamente a través de preguntas indirectas y de largas charlas informales que se pudo establecer esa relación. Una revisión bibliográfica y hemerográfica profundizada permitió establecer antecedentes sobre estas prácticas de clientelismo para entender el uso político que se hizo del programa social de los huertos de stevia, integrándolo a una larga serie de casos (Vilalta, 2007; Hevia 2007, 2010; Bey y Combes, 2011). Si los testimonios de los actores constituyen una fuente básica en este trabajo, su interpretación y su análisis se realizaron gracias a la información de estas fuentes secundarias. program, with access or not to ejido lands, in order to obtain the testimonies of a diversified range of producers. Interviews with women predominated because of the nature of the program, directed at lowincome families, and whose title holder are, in general, the matriarch $s^{2}$. In addition to allowing understanding the history of the crop, the interviews were focused on analyzing the means and livelihood strategies of the households (Scoones, 1998). Thanks to this approach the interactions between macroeconomic policies, local institutions and processes that take place inside the households can be observed, and "the capacities, the assets (reserves, resources, claims and access), the activities and the access to these (through institutions and social relations) can be identified and valued, which as a whole determine the livelihood to which an individual or a household can gain access" (Ellis, 2000). The goods or assets represent the platform for the livelihood strategies, where access to different types of "capitals" (financial, physical, natural, social and human) provides specific capacities to individuals and households to develop their strategies (DFID, 1999) ${ }^{3}$. These interviews, and others carried out with those responsible of the project at different levels (the company's engineers, Prospera's state delegate), allowed evidencing the many contradictions of the project, which can only be explained by establishing their link to the electoral process that took place in the state of Veracruz in 2015. As Auyero (2011) mentions, the relationship systems where the analysis of cronyism is centered cannot be easily seen, which is why it was only through indirect questions and long informal conversations that this relation could be established. A bibliographic and newspaper revision allowed establishing antecedents about these spoils practices to understand the political use that was made of the stevia plantations social program, integrating it to a long series of cases (Vilalta, 2007; Hevia 2007, 2010; Bey and Combes, 2011). If the testimonies of the actors constitute a basic source of information in this study, their interpretation and analysis was carried out thanks to the information of these secondary sources.

\section{The global sweetener market and stevia's situation in México}

For centuries, honey bee and cane and beet sugar were practically the only sweeteners available for human consumption. While sugar cane was brought 


\section{El mercado mundial de endulzantes y la situación de la stevia en México}

Durante siglos, la miel de abeja y el azúcar de caña y de remolacha fueron prácticamente los únicos endulzantes disponibles para el consumo humano. Mientras la caña de azúcar fue traída y expandida en América durante La Colonia, la remolacha se utilizó como endulzante en tierras europeas a partir del siglo XVIII. No obstante el predominio de estos dos endulzantes, durante los últimos 35 años se ha generado una amplia variedad de productos con este mismo propósito (García Almeida et al., 2013), que en su conjunto hoy ocupan $20 \%$ del mercado mundial y equivalen a 34 millones de toneladas de azúcar ${ }^{4}$. La búsqueda incesante de nuevos compuestos ${ }^{5}$ en esta línea ha estado encaminada a obtener cada vez un mayor poder endulzante y un menor aporte energético, en respuesta a cambios en las preferencias de sectores específicos de consumidores.

Mientras tanto, la producción mundial de azúcar ha experimentado cambios ligeros que señalan un constante incremento en su producción que para el ciclo 2008/2009 era de 143.8 millones de toneladas, incrementándose en los siguientes ciclos hasta alcanzar 177.9 en 2012/2013. Desde entonces se ha registrado una disminución paulatina que se observa en los datos para el ciclo 2015/2016 cuando se produjeron 164.9 millones de toneladas (USDA-FASPSD, 2016) ${ }^{6}$. Otras fuentes, como la Organización Internacional del Azúcar (ISO, 2015) ${ }^{7}$, estiman que el consumo global de azúcar aumentó ligeramente de 168.4 millones de toneladas en $2013 / 2014$ a 171.5 millones de toneladas para el ciclo 2014/2015 (1.8\%), mientras que su producción se incrementó solamente de 171 a 172.1 millones de toneladas de 2013/2014 a 2014/2015 (0.6 \%). Esta información muestra que se alcanzó una suerte de estado de equilibrio entre oferta y demanda sin que esto implique que se hayan logrado consumir los excedentes de ciclos anteriores. No obstante, si se incluye la producción de azúcar a partir de remolacha, la producción integral de azúcar disminuyó $1.8 \%$ entre los ciclos 2012/2013 y 2014/2015.

En este contexto, el principal competidor del azúcar a nivel mundial es el jarabe de maíz de alta fructuosa (JMAF), endulzante desarrollado durante la década de 1970 en EUA y actualmente producido en and expanded in America during the Colony, beet was used as sweetener in European lands since the $18^{\text {th }}$ Century. However, the predominance of these two sweeteners, during the last 35 years has generated a broad variety of products with this same purpose (García Almeida et al., 2013), which as a whole occupy $20 \%$ of the global market and are equivalent to 34 million tons of sugar ${ }^{4}$. The unceasing search for new compounds ${ }^{5}$ in this line has been directed at obtaining an increasingly larger sweetening power and a lower energetic contribution, in response to changes in the preferences of specific consumer sectors.

Meanwhile, the global sugar production has experienced slight changes that point to a constant increase in its production which by the 2008/2009 cycle was 143.8 million tons, increasing in the next cycles until reaching 177.9 in 2012/2013. Since then a gradual decrease has been seen in the data for the 2015/2016 cycle when 164.9 million tons were produced (USDA-FAS-PSD, 2016) ${ }^{6}$. Other sources, such as the International Sugar Organization (ISO, $2015)^{7}$, estimate that the global consumption of sugar increased slightly from 168.4 million tons in $2013 / 2014$ to 171.5 million tons for the $2014 / 2015$ cycle $(1.8 \%)$, while its production increased only from 171 to 172.1 million tons from 2013/2014 to $2014 / 2015$ (0.6 \%). This information shows that a sort of state of equilibrium between offer and demand was reached without this implying that the excess from prior cycles were actually consumed. However, if the sugar production from beet is included, the integral sugar production decreased $1.8 \%$ between the cycles of 2012/2013 and 2014/2015.

Within this context, the main sugar competitor at the global level is high fructose corn syrup (HFCS), sweetener developed during the decade of 1970 in the USA and currently produced mostly in that country. The low production prices, and with them the penetration it has had in several countries of the world, make it strongly competitive compared to cane or beet sugar (Secretaria de Economía, 2012). In their turn, non-caloric sweeteners have shown a considerable increase in international markets. According to reports from companies specialized in market analysis, the global market of these substances, not only as prime materials, but rather including the set of byproducts, will be equivalent to 1.9 trillion dollars in 2020 (Global Industry Analysts, 
su mayoría en ese país. Los bajos precios de producción, y con ello la penetración que ha tenido en varios países del mundo, lo hacen fuertemente competitivo respecto al azúcar de caña o remolacha (Secretaria de Economía, 2012). Por su parte, los endulzantes no calóricos han registrado un incremento considerable en los mercados internacionales. De acuerdo con informes de empresas especializadas en análisis de mercado, el mercado global de estas sustancias, no solo como materias primas, sino incluyendo el conjunto de productos derivados, en 2020 equivaldrá a 1.9 billones de dólares (Global Industry Analysts, INC) ${ }^{8}$. El principal obstáculo a la expansión de este tipo de productos son las críticas a los endulzantes no calóricos sintéticos (como el aspartamo, la sucralosa, la sacarina), con más o menos bases científicas, según sea el caso, en relación con los posibles efectos secundarios nocivos que podrían tener en la salud de los consumidores (toxicidad, carcinogénesis, entre otros) (García Almeida et al., 2013).

En medio de este escenario, la stevia (Stevia rebaudiana) presenta características específicas: es una planta originaria de Paraguay de cuyas hojas se extraen dos sustancias altamente endulzantes (esteviósido y rebaudiósido) y tradicionalmente usada con distintos fines. En la década de 1970 apareció en el mercado japonés y después de reunirse pruebas científicas de su inocuidad estos extractos fueron aprobados para ser introducidos en el mercado norteamericano una década después (García Almeida et al., 2013). A principios de este siglo fueron ampliamente distribuidos por grandes compañías transnacionales. ${ }^{9}$. Tiene un alto poder endulzante (300 veces mayor que el de la azúcar de caña), se puede conservar sin modificaciones en el sabor y sin ganar toxicidad, aun a altas temperaturas; además, su carácter natural y sus diversas propiedades curativas ${ }^{10}$ le confieren ventajas importantes para competir favorablemente en mercados diferenciados. Tales cualidades explican las estimaciones de la Agencia Internacional Zenith, respecto al aumento en $14 \%$ en las ventas de stevia, tan solo entre 2013 y 2014 a nivel mundial, alcanzando $4670 \mathrm{t}$ con un valor de 336 millones de dólares, y se espera que este monto continúe ascendiendo hasta obtener 578 millones de dólares en 2017 por un total de 7150 t (Food Business News, 2014) ${ }^{11}$. Su consumo se ha expandido a más de 60 países, particularmente en América Latina; de acuerdo con datos de la consultora Mintel, el número de productos endulzados con stevia crece a un ritmo de $53 \%$ anual ${ }^{12}$.
INC $)^{8}$. The main obstacle for the expansion of this type of products is criticism to non-caloric synthetic sweeteners (such as aspartame, sucralose, saccharine), with more or less scientific bases, depending on the case, in relation to the possible harmful secondary effects that they may have on the health of consumers (toxicity, carcinogenesis, among others) (García Almeida et al., 2013).

Within this scenario, stevia (Stevia rebaudiana) presents specific characteristics: it is a native plant of Paraguay from whose leaves two highly sweetening substances are extracted (stevioside and rebaudioside), and traditionally used for different purposes. During the decade of 1970 it appeared in the Japanese market and after scientific proof of the harmlessness of these extracts was gathered, they were approved to be introduced in the US market a decade later (García Almeida et al., 2013). At the beginning of this century it was widely distributed by large transnational companies ${ }^{9}$. It has a high sweetening power (300 higher than cane sugar), can be conserved without modifications to its flavor and without gaining toxicity, even at high temperatures; also, its natural character and its various healing properties ${ }^{10}$ give it important advantages to compete favorably in differentiated markets. These qualities explain the estimations of the International Zenith Agency, with regards to the increase of $14 \%$ in stevia sales, just between 2013 and 2014 at the global level, reaching $4670 \mathrm{t}$ with a value of 336 million dollars, and it is expected for this sum to continue increasing up to obtaining 578 million dollars in 2017 for a total of $7150 \mathrm{t}$ (Food Business News, 2014 $)^{11}$. Its consumption has expanded to more than 60 countries, particularly in Latin America; according to data from Mintel consulting, the number of products sweetened with stevia grows at a rate of $53 \%$ annually ${ }^{12}$.

In the case of México and its sweetener market, the sugar cane production has been growing since colonial times, not only because of its dietary importance but rather because of the economic, social and cultural implications that it has had throughout the country's history. Currently, the difficulties that the sugar cane sector is undergoing obey to technological deficiencies, both in the cultivation and in the industrial processing, in addition to bad administrative and economic management. On the other hand, the decrease that sugar consumption has experienced responds to 
En el caso de México y de su mercado de endulzantes, la producción de cańa de azúcar ha sido creciente desde tiempos coloniales, no solo por su importancia alimenticia sino por las implicaciones económicas, sociales y culturales que ha tenido a lo largo de la historia del país. En la actualidad, las dificultades que atraviesa el sector cañero obedecen a deficiencias tecnológicas, tanto en el cultivo como en el procesamiento industrial, aunadas a malos manejos administrativos y económicos. Por otra parte, la disminución que ha experimentado el consumo de azúcar obedece a la competencia que representa la incursión en el mercado de nuevos endulzantes, particularmente el JMAF (Secretaria de Economía, $2012,4)$. La introducción y posterior producción de este endulzante a nivel nacional fue propiciada por el TLCAN, en condiciones de gran tensión debido al manejo discrecional de los acuerdos. Se reporta un incremento de $2000 \%$ en las importaciones de JMAF desde EUA entre 2002 y 2014 (de 35752 tcbs en 2002 a 802272 tcbs en 2014, con picos por encima de un millón de tcbs en 2011 y 2012) ${ }^{13}$. En la actualidad, el consumo nacional de JMAF representa el $30 \%$ entre los endulzantes calóricos, mientras que el azúcar cubre prácticamente el $70 \%$ restante. Aunado a esto, entre 1970 y 2010 el consumo anual promedio per capita de azúcar en México bajó de 50 a $42 \mathrm{~kg}$ (García Chávez, 2011). Este descenso se explica por cambios en las preferencias de sectores específicos de consumidores, así como por la promoción de políticas públicas encaminadas a desincentivar la ingesta de productos que incluyen azúcar en su formulación ${ }^{14}$.

Como en otros países de Latinoamérica, el consumo de stevia ha crecido de manera vertiginosa en los últimos cinco años ${ }^{15} \mathrm{y}$ el cultivo se ha empezado a desarrollar en varias partes de la República Mexicana durante la última década. Según el Servicio de Información Agroalimentaria y Pesquera (SIAP, 2014), la producción aún modesta en 2014 fue de 218 t, con solo 58 ha sembradas en los estados de Nayarit, Chiapas, Veracruz, Quintana Roo y Campeche (SIAP, 2014). Sin embargo, se encuentran importantes áreas con vocación para el cultivo en los estados de Michoacán, Jalisco, Veracruz, Chiapas, Yucatán, Quintana Roo y Campeche (Sagarpa, 2013). En 2015, la extensión más importante estaba en Quintana Roo y Campeche, donde la empresa Stevia Maya -perteneciente al grupo Pegaso y que trabajaba en the competition that the incursion into the market of new sweeteners represents, particularly HFCS (Secretaria de Economía, 2012, 4). The introduction and later production of this sweetener at the national level was fostered by NAFTA, under conditions of great tension due to the discretional handling of the agreements. An increase of $2000 \%$ in HFCS imports from the USA is reported between 2002 and 2014 (from 35752 tcbs in 2002 to 802272 tcbs in 2014, with peaks above a million tcbs in 2011 and 2012 $)^{13}$. Nowadays, the national consumption of HFCS represents $30 \%$ among caloric sweeteners, while sugar practically covers the remaining $70 \%$. In addition to this, between 1970 and 2010 the average annual per capita sugar consumption in México decreased from 50 to $42 \mathrm{~kg}$ (García Chávez, 2011). This decrease is explained by changes in the preferences of specific sectors of consumers, as well as by the promotion of public policies directed at discouraging the intake of products that include sugar in their formulation ${ }^{14}$.

As in other Latin American countries, the consumption of stevia has increased vertiginously in the last five years ${ }^{15}$ and the crop has begun to develop in several parts of the Mexican Republic during the last decade. According to the Agrifood and Fishing Information Service (Servicio de Información Agroalimentaria y Pesquera, SIAP, 2014), the production, although modest in 2014, was 218 $\mathrm{t}$ with only 58 ha sown in the states of Nayarit, Chiapas, Veracruz, Quintana Roo and Campeche (SIAP, 2014). However, important useful areas for the crop are found in the states of Michoacán, Jalisco, Veracruz, Chiapas, Yucatán, Quintana Roo and Campeche (Sagarpa, 2013). In 2015, the most important area was in Quintana Roo and Campeche, where the company Stevia Maya - which belongs to the Pegaso group and worked in collaboration with the National Institute of Agricultural, Livestock and Forestry Research (Instituto Nacional de Investigación Forestales Agropecuarias y Pecuarias, INIFAP) - began to operate since the year 2009 (Stevia Maya, 2015) ${ }^{16}$.

\section{Stevia cultivation in the region of Los Tuxtlas ${ }^{17}$}

In the state of Veracruz, cultivation began in Los Tuxtlas, a region with uneven topography determined by a mountainous range of volcanic origin, whose peak is at $1650 \mathrm{~m}$ (Figure 1). 
colaboración con el Instituto Nacional de Investigación Forestales Agropecuarias y Pecuarias (INIFAP) empezó a operar desde el año 2009 (Stevia Maya, 2015) $)^{16}$.

\section{El cultivo de la stevia en la región de Los Tuxtlas ${ }^{17}$}

En el Estado de Veracruz, el cultivo empezó en Los Tuxtlas, región con accidentada topografía determinada por un macizo montañoso de origen volcánico, cuya cima se encuentra a $1650 \mathrm{~m}$ (Figura 1).

Su vertiente oriental se perfila hacia el mar, lo que da lugar a un régimen de precipitaciones constantes y abundantes a lo largo del ańo (por encima de los $4500 \mathrm{~mm}$ ) y temperaturas que fluctúan entre los 21 y $27^{\circ} \mathrm{C}$. Es un clima cálido-húmedo que permite el florecimiento de la selva alta perennifolia más septentrional de todo el continente americano, la cual alberga una alta biodiversidad de especies. Aunque la
Its eastern slope faces the sea, which gives rise to a regime of constant and abundant rainfall throughout the year (above $4500 \mathrm{~mm}$ ) and temperatures that fluctuate between 21 and $27{ }^{\circ} \mathrm{C}$. It is a warmhumid climate that allows the development of the northernmost evergreen high rainforest of the whole American continent, which houses a high biodiversity of species. Although traditional milpa sowing for autoconsumption continues up until today, in this region of ancient indigenous population recently sugar cane and tobacco crops have been sown, while livestock production expanded significantly throughout the region, until becoming the main economic activity.

In this scenario, the stevia crop appeared at the beginning of 2012 when Dr. Juan Manual Rayas Arvizu, originally from the region and president of the company Complejo de Investigación y Desarrollo Herbolario (CIDH S.A. de C.V.), installed in Paso del Toro and belonging to the Rayca consortium, began to be interested in the plant. He hired an agronomist

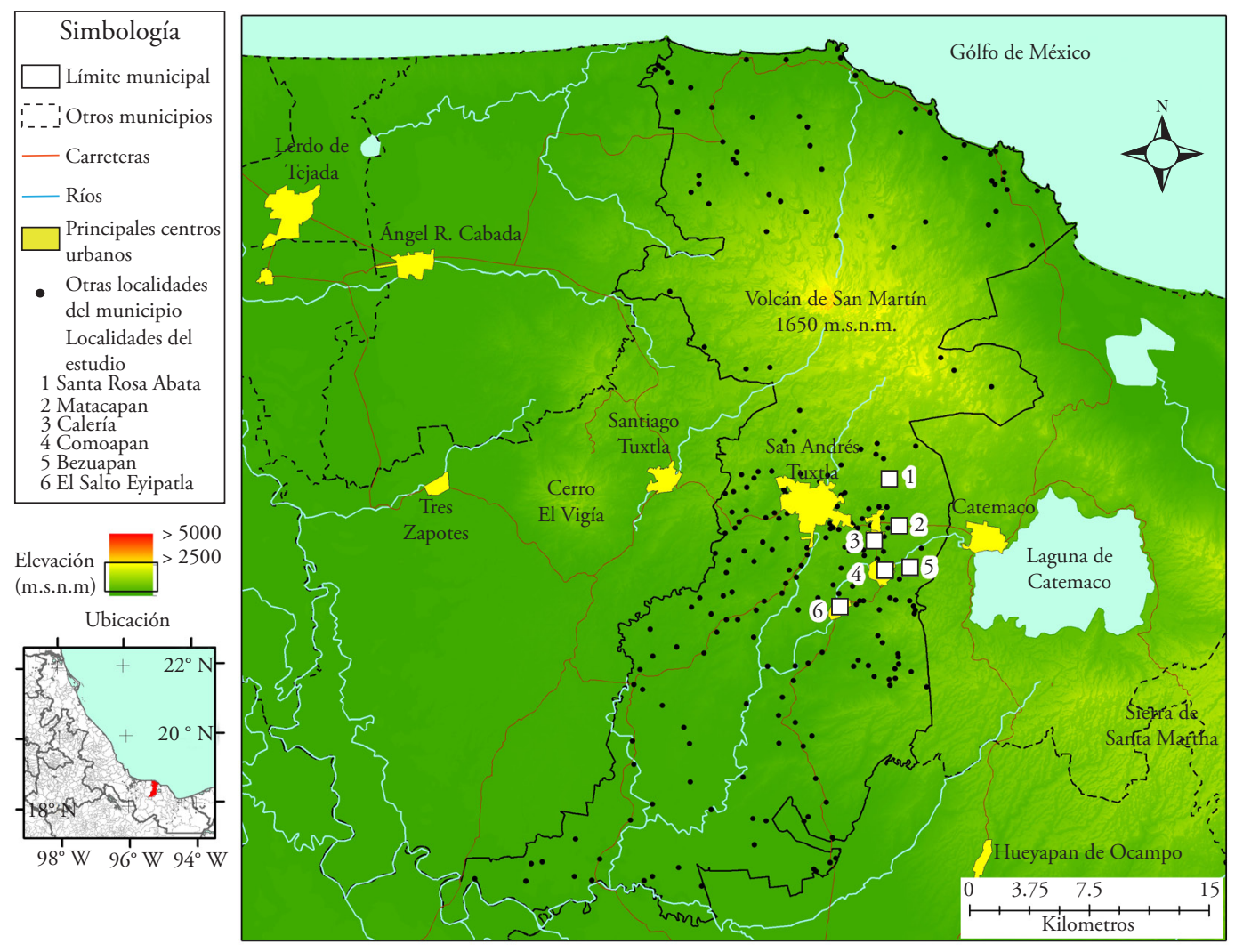

Figura 1. La región de Los Tuxtlas, Veracruz, México y las localidades de adaptación del cultivo de stevia donde se realizaron las entrevistas.

Figure 1. The region of Los Tuxtlas, Veracruz, México, and the localities of the stevia crop adaptation where the interviews were performed. 
siembra tradicional de milpa de autoconsumo continúa hasta nuestros días, en esta región de antigua población indígena recientemente se siembran cultivos de caña de azúcar y tabaco, mientras la ganadería se expandió de manera significativa por toda la región, hasta llegar a ser la principal actividad económica.

En este escenario, el cultivo de la stevia apareció a inicios de 2012 cuando el Doctor Juan Manual Rayas Arvizu, originario de la región y presidente de la empresa Complejo de Investigación y Desarrollo Herbolario (CIDH S.A. de C.V.), instalada en Paso del Toro y perteneciente al consorcio Rayca, empezó a interesarse por la planta. Contrató a un ingeniero agrónomo para reproducirla en invernaderos e indagar mediante el análisis de sus características, sobre su posibilidad de adaptación a las condiciones climáticas y edafológicas de la región. Se sembraron 3 ha en el rancho Neyama, en San Andrés Tuxtla, a 3 km al norte de la cabecera municipal. A inicios de 2013 se amplió el proyecto con la contratación de otro ingeniero agrónomo y un nuevo plantío de 3.5 ha en tierras rentadas del ejido de Matacapan, $5 \mathrm{~km}$ al sur de San Andrés Tuxtla.

El año siguiente, el proyecto tomó un giro cuando la empresa Rayca contactó al Lic. Jorge Carvallo Delfín, en aquel entonces Presidente de la Secretaría de Desarrollo Social (SEDESOL) del Estado de Veracruz. El Lic. Carvallo mostró gran interés por el cultivo que estaba en pleno auge en otras regiones de México y cuyo consumo comenzaba a ser más visible en el mercado nacional. SEDESOL promovió entonces la idea de asociar al cultivo de la stevia y a la empresa el programa de inclusión social Prospera. El cultivo, muy demandante en atenciones y mano de obra, solo se puede trabajar en superficies reducidas (Ramírez, 2011), por lo cual se consideró implicar a las beneficiarias de Prospera, quienes iban a sembrar las plantas en sus traspatios sin grandes inversiones mediante un tipo de cooperación que podía convenir tanto a la empresa Rayca como a las productoras. Para SEDESOL, involucrarse y financiar el proyecto de huertos de stevia iba a permitir, según el delegado estatal de Prospera en el estado de Veracruz, Alejandro Baquedano Sánchez, transformar el programa de solo dar transferencias, en un proyecto productivo $^{18}$. Era un giro en las líneas de acción del programa, el cual se expone en las reglas de operación (Diario Oficial, 2014) ${ }^{19}$. A la SEDESOL le correspondía comprar las plantas a la empresa y entregarlas engineer to reproduce it in greenhouses and to inquire, through the analysis of its characteristics, about the possibility to adapt it to the climate and soil conditions of the region. In the Neyama ranch, San Andrés Tuxtla, $3 \mathrm{~km}$ north of the municipal township, 3 ha were planted. At the beginning of 2013 the project was expanded with the hiring of another agronomist engineer and a new plantation of 3.5 ha in lands rented from the Matacapan ejido, 5 $\mathrm{km}$ south of San Andrés Tuxtla.

The following year, the project took an unexpected turn when the Rayca company hired Mr. Jorge Carvallo Delfín, at the time President of the Ministry of Social Development (Secretaria de Desarrollo Social, SEDESOL) of the state of Veracruz. Mr. Carvallo showed great interest over the crop that was in full boom in other regions of México and whose consumption was beginning to be more visible in the national market. SEDESOL then promoted the idea of associating the stevia crop and the company to the social inclusion program Prospera. The crop, quite demanding in attention and labor, could only be farmed in reduced surfaces (Ramírez, 2011), which is why it was thought to imply the Prospera beneficiaries, who would sow the plants in their backyards without large investments through a type of cooperation that could be convenient both for the Rayca Company and for the producers. For SEDESOL, to become involved and finance the project of stevia plantations would allow, according to the state delegate of Prospera in the state of Veracruz, Alejandro Baquedano Sánchez, transforming the program of only allotting transferences into a productive project ${ }^{18}$. It was a shift in the action lines of the program, which is explained in the operation rules (Diario Oficial, 2014) ${ }^{19}$. SEDESOL was in charge of purchasing the plants from the company and delivering them to the producers. The Rayca company was committed to cultivating the seedlings necessary and SEDESOL to selling them, providing the producers with technical assistance and certain organic products needed for the $\operatorname{crop}^{20}$, and purchasing the dry leaves at the end of the process. The Prospera title holders had the task of receiving the seedlings, carrying out the whole productive process of stevia, and selling the dry leaves in bags to Rayca at a price fixed by the company of $\$ 350$ per $\mathrm{kg}$, from which they would be able to increase their income in a substantial way. It 
a las productoras. La empresa Rayca se comprometía a cultivar los plantines necesarios a SEDESOL y vendérselo, dar la asesoría técnica y ciertos productos orgánicos necesarios para el cultivo a las productoras ${ }^{20}$, y comprar las hojas secas al final del proceso. A las titulares de Prospera les tocaba recibir los plantines, llevar a cabo todo el proceso productivo de la stevia y vender las hojas secas en bolsas a Rayca a un precio fijado por la empresa de $\$ 350$ por $\mathrm{kg}$, por lo cual iban a poder aumentar sus ingresos de manera sustantiva. Parecía entonces que cada una de las partes asociadas al proyecto iba a obtener ciertos beneficios.

En abril 2014 la SEDESOL organizó una primera reunión con las vocales de Prospera en Salto de Eyipantla, comunidad del municipio de San Andrés Tuxtla, para informarles de la posibilidad de cultivar esta nueva planta, y de las características y condiciones de cultivo. La empresa Rayca proponía empezar con un proyecto piloto para evaluar tanto la factibilidad de la implantación del cultivo en la región, como los problemas a los cuales se iban a enfrentar las productoras. En mayo 2014, SEDESOL entregó los plantines a cinco productoras que reunían las condiciones para el proyecto ${ }^{21}$-tener una parcela propia o de renta donde sembrar, con acceso a agua para riego y sin árboles que afectarían el cultivo con su sombra-, y se plantaron los primeros huertos. Los agrónomos de la empresa dieron asesoría al momento de plantar y visitaron los huertos con regularidad para ver la evolución de las plagas y explicar a las productoras cómo eliminarlas. Uno de los principales problemas es que las condiciones climáticas de Los Tuxtlas favorecen la proliferación de hongos y otras plagas que afectan la planta. El primer corte se hizo en agosto de 2014 y, aunque la empresa Rayca y SEDESOL habían avisado que el kilo se iba a pagar a $\$ 350.00$, cada una de las productoras recibió $\$ 10000$, sin tomar en cuenta el peso, que osciló entre 10 y $20 \mathrm{~kg}$ por entrega ${ }^{22}$.

Después de esta primera experiencia, SEDESOL organizó otras reuniones de información en comunidades vecinas de Salto de Eyipantla para convencer a más titulares de Prospera de plantar stevia. El precio ofrecido a las cinco productoras del proyecto piloto fue el mejor incentivo en comunidades donde el trabajo escasea. Nuevas productoras de las comunidades de Bezuapan, Comoapan, Salto de Eyipantla, Santa Rosa Abata, Huidero, Tilapan, Chuniapan de Arriba y Soyata se incorporaron al proyecto en agosto y seemed then that each one of the parts associated to the project would obtain certain benefits.

In April 2014, SEDESOL organized a first meeting with the vocals of the Pospera program in Salto de Eyipantla, community from the municipality of San Andrés Tuxtla, to inform them of the possibility of cultivating this new plant, and of the characteristics and conditions of the crop. The Rayca company suggested starting with a pilot project to evaluate both the feasibility of implanting the crop in the region and the problems that producers would face. In May 2014, SEDESOL delivered the seedlings to five producers who met the conditions for the project ${ }^{21}$ - having a plot of their own or to rent where to plant, with access to irrigation water and without trees that would affect the crop with their shade - and the first plantations were sown. The agronomists from the company gave assistance at the time of planting and visited the plantations regularly to oversee the evolution of pests and explain to the producers how to eliminate them. One of the main problems is that climate conditions in Los Tuxtlas favor the proliferation of fungi and other pests that affect the plant. The first cut was done in August 2014 and, although the Rayca company and SEDESOL had said that the kilogram would be paid at $\$ 350.00$, each of the producers received $\$ 10$ 000 , without taking into account the weight, which ranged between 10 and $20 \mathrm{~kg}$ per delivery ${ }^{22}$.

After this first experience, SEDESOL organized other information meetings in communities neighboring Salto de Eyipantla to convince even more Prospera title holders about planting stevia. The price offered to the five producers from the pilot project was the best incentive in communities where work is scarce. New producers from the communities of Bezuapan, Comoapan, Salto de Eyipantla, Santa Rosa Abata, Huidero, Tilapan, Chuniapan de Arriba and Soyata were incorporated into the project in August and September 2014. It was approximately 100 plantations, each with 1000 seedlings in average and $100 \mathrm{~m}^{2}$ of surface, which appeared near the households: in the backyards or between the street and the house, whenever there was no space behind. The plants were also planted in ejido plots located on the periphery of the towns. The producers who did not have backyards sought to rent or ask for a piece of land as a loan from neighbors or relatives, always respecting the basic conditions: access to water and 
septiembre de 2014. Fueron aproximadamente 100 huertos, cada uno de 1000 plantines en promedio y $100 \mathrm{~m}^{2}$ de superficie, que aparecieron cerca de las casas: en los traspatios o entre la calle y la casa, en caso de no haber espacio atrás. Las plantas se implantaron también en parcelas ejidales situadas en la periferia de los poblados. Las productoras que no tenían solares buscaron rentar o pedir prestado un pedazo a vecinos o familiares, siempre respetando las condiciones básicas: con acceso al agua y sin sombra. La empresa Rayca siguió con su tarea de capacitación, teniendo como interlocutoras principales a las vocales de Prospera, que posteriormente pasaban la información a las titulares involucradas.

En noviembre 2014 la SEDESOL a nivel federal se integró al proyecto de los huertos veracruzanos de stevia y le dio de repente una dimensión más importante. El impulso del cultivo en el estado de Veracruz, que se dio al mismo tiempo que se publicaron las nuevas reglas de operación de Prospera en el Diario Oficial (2014), tenía como objetivo permitir a las beneficiarias fomentar sus capacidades productivas y obtener ingresos económicos de su producción. Representó un proyecto modelo para SEDESOL a nivel federal, la cual empezó a financiar nuevos huertos en las mismas localidades y en otras de la región. Anunció como objetivo la implantación a corto plazo de 4000 huertos $^{23}$, gracias a un presupuesto de $54 \mathrm{mi}$ llones de pesos ${ }^{24}$, destinado a la compra de las plantas y al financiamiento de la asesoría técnica.

La empresa Rayca pagó las entregas de hojas secas, correspondiendo a los cortes efectuados en varias localidades en los meses de noviembre y diciembre de 2014, en $\$ 1000$ el kilogramo, lo que casi triplicó nuevamente el precio anunciado previamente, aunque la SEDESOL explicó que fue una manera de compensar la baja producción generalizada de esta cosecha debida a problemas en la asesoría ${ }^{25}$, varias de las titulares de Prospera intuyeron que ese seguiría siendo el precio. En pocos meses se apuntaron en las listas de SEDESOL a nivel federal, centenares de titulares de Prospera.

\section{Cambios en las estrategias de sustento de los hogares provocados por el cultivo}

Respecto al acceso a capitales, resulta paradójico que en la región de Los Tuxtlas se ha impulsado un gran número de proyectos de desarrollo por parte de without shade. The Rayca company continued with its task of training, having as main interlocutors the vocals from Prospera, who later passed on the information to the title holders involved.

In November 2014, SEDESOL at the federal level was integrated to the project of the Veracruz stevia plantations and suddenly a more important dimension was given to it. The promotion of the crop in the state of Veracruz, which took place at the same time that the new operation rules from Prospera were published in the official government journal, Diario Oficial (2014), had the objective of allowing the beneficiaries to foster their productive capacities and obtain economic income from its production. It represented a model project for SEDESOL at the federal level, which began to finance new plantations in the same localities and in others in the region. It announced as objective the implantation in the short term of 4000 plantations $^{23}$, thanks to a budget of 54 million $\operatorname{pesos}^{24}$, destined to the purchase of plants and to the financing of technical consulting.

The Rayca company paid the deliveries of dry leaves, corresponding to the cuts carried out in several localities during the months of November and December 2014, at $\$ 1000$ per kilogram, which nearly tripled again the price announced previously, although SEDESOL explained that it was a way to compensate the generalized low production of this crop due to problems in the consultancy ${ }^{25}$; many of the Prospera title holders suspected that this would continue to be the price. In a few months, hundreds of Prospera title holders signed up on the SEDESOL lists at the federal level.

\section{Changes in the sustenance strategies of the households caused by the crop}

Regarding access to capitals, it is paradoxical that in the region of Los Tuxtlas a large number of development projects have been promoted by government institutions, international agencies, scholars, and NGOs (Paré, 1996; Paré and Robles, 2005; Casados, 2008; Cruz and Valencia, 2009; Piñar et al., 2012). However, these initiatives have not been able to counteract the difficulties that the insufficiency of work opportunities and the withdrawal of state support to the countryside represent, as well as the demographic growth and fragmentation of lands in the zone. Although the diversification of household 
instituciones gubernamentales, agencias internacionales, académicos y OSCs (Paré, 1996; Paré y Robles, 2005; Casados, 2008; Cruz y Valencia, 2009; Piñar et al., 2012). Sin embargo, estas iniciativas no han podido contrarrestar las dificultades que representan la insuficiencia de oportunidades laborales y el retiro del apoyo estatal al campo, así como el crecimiento demográfico y la fragmentación de tierras en la zona. Si bien no es reciente la diversificación de los ingresos de los hogares, ni la participación de uno o más de sus miembros en los mercados formales de trabajo no agropecuario, llama la atención la masificación de estos procesos (Léonard, 2003). Durante las últimas décadas se han intensificado los flujos migratorios fuera de la región y hacia lugares cada vez más lejanos más allá de las fronteras nacionales (Léonard, 2003).

La ineficacia de los esfuerzos para impulsar el desarrollo se refleja en las precarias condiciones de vida que prevalecen en las comunidades de estudio. El Censo de Población y Vivienda (INEGI, 2010) muestra que el porcentaje de personas analfabetas en las localidades (entre 12 y $21 \%$ ) se sitúa en todos los casos por encima del nacional (5.8\%), siendo siempre mayor el porcentaje de mujeres respecto al de hombres. Se registran altos porcentajes de población (26 a $65 \%$ ) que en estas localidades no cuentan con acceso a los servicios de salud. La vulnerabilidad de gran cantidad de hogares se aprecia también en el número de jefaturas femeninas equivalentes al rango de 17 a $26 \%$ de los grupos domésticos (INEGI, 2010).

Por otro lado, la transformación de las actividades productivas se aprecia en la distribución de la Población Económicamente Activa por sector reportada para la región: $35 \%$ en el primario, $45 \%$ en el de servicios, y $17 \%$ en el manufacturero. Los datos oficiales reportan altos porcentajes de población ocupada en estas localidades (76 a $85 \%$, siendo siempre significativamente inferiores en el caso de las mujeres), pero no logran capturar de manera precisa el carácter temporal y las significativas fluctuaciones estacionales en muchas de las ofertas laborales en la zona.

En el caso del acceso a servicios públicos, INEGI (2010) reporta que porcentajes bajos (1 a $9 \%$ ) de las viviendas en estas localidades carecen de electricidad. La proporción de viviendas que no disponen de entubada fluctúa entre 13 y $29 \%$ en las distintas localidades. En este mismo sentido, las carencias en servicios de salud, educación y servicios básicos se reflejan en income is not recent, nor the participation of one or more of its members in the formal markets of nonagricultural/livestock work, the widespread growth of these processes draws attention (Léonard, 2003). During recent decades the migratory flows have been intensified outside the region and toward increasingly farther places beyond the national borders (Léonard, 2003).

The inefficacy of the efforts to drive development is reflected in the precarious living conditions that prevail in the communities of study. The Population and Housing Census (INEGI, 2010) shows that the percentage of illiterate people in the localities (between 12 and $21 \%)$ is in all cases above the national (5.8\%), with the percentage of women always being higher than that of men. High percentages of the population (26 to $65 \%$ ) are found who in these localities do not have access to health services. The vulnerability of a large number of households is also appreciated in the number of women heads of household equivalent to the range from 17 to $26 \%$ of the domestic groups (INEGI, 2010).

On the other hand, the transformation of the productive activities is appreciated in the distribution of the Economically Active Population per sector reported for the region: $35 \%$ in the primary, 45 $\%$ in services, and $17 \%$ in the manufacturing. Official data report high percentages of occupied population in these localities (76 to $85 \%$, being always significantly lower in the case of women), but they do not manage to capture precisely the temporal character and the significant seasonal fluctuations in many of the work offers in the zone.

In the case of access to public services, INEGI (2010) reports that low percentages (1 to $9 \%$ ) of the households in these localities lack electricity. The proportion of households that do not have piped water fluctuates between 13 and $29 \%$ in the different localities. In this same sense, the shortages in health services, education and basic services are reflected in the high degree of marginalization that is found in all the localities, according to the evaluations performed by CONAPO (2010).

\section{An economy based on the temporary work and state backing}

The field work allows perfecting and complementing statistical information in terms of the livelihood 
el alto grado de marginación que registran todas las localidades, de acuerdo con las evaluaciones hechas por CONAPO (2010).

\section{Una economía basada en el trabajo temporal y los apoyos estatales}

El trabajo de campo permite afinar y complementar la información estadística en cuanto a las estrategias de vida y los ingresos. Según los testimonios, en estas localidades la mayoría de la población masculina se emplea como jornaleros de manera eventual, en los cultivos de tabaco y de maíz, por un sueldo de $\$ 1500$ a $\$ 2000$ pesos mensuales. Otros hombres trabajan en las bodegas de tabaco y en la construcción, con condiciones económicas similares. En algunos casos, los jefes de familia se han ido a trabajar fuera, a otra parte del país o a EE.UU. y mandan dinero. Estos ingresos se complementan a veces con las actividades de las mujeres (ventas por catálogo o de antojitos en el pueblo, tiendas de abarrotes, cría de puercos y gallinas) y con el apoyo Procampo para los ejidatarios.

En este contexto, las becas y los apoyos de Prospera constituyen una parte importante de los ingresos. Según las normas de la SEDESOL (Diario Oficial, 2014), las becas varían entre $\$ 175.00$ y $\$ 1120.00$ mensuales por alumno, según el sexo y el grado de estudio, a las cuales se suma un monto fijo de $\$ 335.00$ mensuales de apoyo alimentario y $\$ 140.00$ mensuales de apoyo alimentario complementario para cada titular de Prospera. En el caso de PC, por ejemplo, vocal de Prospera, de 32 años, de la comunidad de Bezuapan, la situación laboral varía según las temporadas. AR, su esposo, trabaja como jornalero y en empleos temporales, con un pago de $\$ 180.00$ diarios en promedio ${ }^{26}$, pero ha pasado temporadas de hasta dos semanas sin trabajo. PC hace manualidades (cojines, bolsas cocidas y adornadas), cuya venta le ayuda, sobre todo, en los periodos en que su esposo no trabaja. Su hija de 16 años estudia el Telebachillerato y su hijo de 13 años acaba de abandonar la Secundaria. Por lo tanto, cada dos meses, PC recibe $\$ 950.00$ de apoyo alimentario y $\$ 3060.00$ de beca de su hija, o sea, un total de $\$ 2005.00$ mensuales, el único ingreso estable, más o menos equivalente a lo que AR y PC ganan mensualmente de su trabajo y ventas. En el caso de NC, de 28 años, de la comunidad de Comoapan, la beca de $\$ 175.00$ de la hija que está strategies and incomes. According to the testimonies, in these localities most of the masculine population is employed occasionally as day laborers, in the tobacco and maize crops, for a wage of $\$ 1500$ to $\$ 2000$ pesos monthly. Other men work in the tobacco storehouses and in construction, with similar economic conditions. In some cases, the heads of households have left to work outside the locality, to another part of the country or to the USA and they send money. These incomes are sometimes complemented with the women's activities (selling catalog products or snacks in the town, grocery stores, breeding pigs and hens), and with the backing from Procampo for the ejido members.

Within this context, the scholarships and supports from Prospera constitute an important part of the incomes. According to the norms from SEDESOL (Diario Oficial, 2014), the scholarships vary between $\$ 175.00$ and $\$ 1120.00$ monthly per student, according to the sex and degree of study, which add up to a fixed amount of $\$ 335.00$ monthly of dietary support and \$140.00 monthly from complementary dietary support for each Prospera title holder. In the case of PC, for example, 32-year-old Prospera vocal from the community of Bezuapan, the labor situation varies according to the seasons. AR, her husband, works as a day laborer and in seasonal employment, with payment of $\$ 180.00$ daily in average $^{26}$, although there have been periods of up to two weeks without work. PC makes handcrafts (cushions, sown and adorned bags), of which the sales help, particularly during the periods when her husband doesn't work. Their 16-year-old daughter studies the Telebachillerato (distant learning high school) and their son of 13 has just dropped out of secondary school. Therefore, every two months, PC receives $\$ 950.00$ for dietary support and $\$ 3060.00$ for her daughter's scholarship; that is, a total of $\$ 2005.00$ monthly, the sole stable income, more or less equivalent to what $\mathrm{AR}$ and $\mathrm{PC}$ earn monthly from their work and sales. In the case of $\mathrm{NC}$, 28-year-old from the community of Comoapan, the scholarship of $\$ 175.00$ of the daughter in primary school and the dietary support add up to a total of $\$ 650.00$ monthly, so the family's situation is more precarious. M, NC's 30-year-old husband, works as a laborer two or three days a week, depending on the demand, and she helps an aunt in her groceries store three afternoons per week. The family income can reach $\$ 2000.00$ monthly, at most. In these two 
en Primaria y el apoyo alimentario suman un total de $\$ 650.00$ mensuales, por lo que la situación de la familia es más precaria. M, el esposo de NC, de 30 años, trabaja como peón dos o tres días a la semana, según la demanda, y ella ayuda a una tía en su tienda de abarrotes tres tardes a la semana. Los ingresos de la familia pueden alcanzar $\$ 2000.00$ mensuales como máximo. En estos dos casos representativos de las familias de las comunidades los ingresos permiten cubrir los gastos básicos (comida diaria, luz, agua, gas, pasajes, anualidades y útiles escolares), pero cualquier imprevisto, por ejemplo, de salud ${ }^{27}$, difícilmente puede ser resuelto sin la contratación de deudas. La situación de los ejidatarios parece no diferir mucho. EC, ejidatario de El Periconal y habitante de la comunidad de Comoapan, tiene 3.5 ha, que siembra principalmente de maíz para la venta y el consumo de su familia (siete personas). Obtiene entre 10 y 15 t de los dos ciclos de cultivo (tapachole y temporal): conserva alrededor de $400 \mathrm{~kg}$ para el consumo del hogar y vende lo restante en $\$ 2.50$ el kg a intermediarios que vienen de Salto de Eyipantla y San Andrés Tuxtla. Además, cultiva frijol en combinación con el maíz y cacahuates en pequeñas superficies. Los ingresos anuales del campo suman aproximadamente $\$ 35000$, de las cuales habría que restar los gastos de insumos y mano de obra. Los apoyos de Prospera y Procampo representan un ingreso anual menor, de aproximadamente $\$ 25000$, pero son más estables y repartidos en todo el año, a la diferencia de los ingresos del campo que pueden ser muy variables y se concentran en dos o tres temporadas anuales. La comparación de estos hogares de ejidatarios con los anteriores indica que el acceso a la tierra no cambia fundamentalmente la situación, por tratarse de superficies reducidas y de cultivos poco rentables.

\section{Cambios sociales, económicos y territoriales}

Este escenario de marginación y de constante inseguridad en el acceso a ingresos permite valorar el impacto que tuvo la aparición de la stevia en las economías de los hogares de Los Tuxtlas que adoptaron el cultivo. En agosto del 2014, cuando las primeras entregas se pagaron en $\$ 10000$, este monto pudo equivaler a lo que se ganaba en el hogar durante una temporada de tres o cuatro meses. El dinero sirvió para la compra de despensas básicas, gastos médicos, e incluso, en algunos casos, para el reembolso de deudas contratadas cases, representative of the communities' families, the incomes allow covering basic expenses (daily food, electricity, water, gas, transport, annuities and school supplies), but any unforeseen event, for example, in health ${ }^{27}$, can hardly be solved without taking on debts.

The situation of ejidatarios seems not to differ much. EC, ejidatario from El Periconal and resident of the community of Comoapan, has 3.5 ha, which he sows mainly with maize for the sale and consumption by his family (seven people). They obtain between 10 and $15 \mathrm{t}$ from the two cultivation cycles (tapachole and rainfed): they keep around $400 \mathrm{~kg}$ for the consumption of the household and sell the remainder at $\$ 2.50$ per kg to intermediaries that come from Salto de Eyipantla and San Andrés Tuxtla. Also, they grow bean in combination with maize and peanut in small surfaces. The annual incomes from the field add up to approximately $\$ 35000$, from which the expenses in inputs and labor should be subtracted. The backing from Prospera and Procampo represents a lower annual income, of approximately $\$ 25000$, but they are more stable and distributed throughout the year, in contrast with the field incomes that can be quite variable and are concentrated in two or three annual seasons. The comparison of these ejidatario households with the prior ones indicates that access to land does not fundamentally change the situation, because they are small areas with low profitability crops.

\section{Social, economic and territorial changes}

This scenario of marginalization and constant insecurity in the access to income allows evaluating the impact that the appearance of stevia had in the economies of the households of Los Tuxtlas which adopted the crop. In August 2014, when the first deliveries were paid at $\$ 10000$, this amount could be equivalent to what was earned in the household during a period of three or four months. The money served for the purchase of basic baskets, for medical expenses, and even, in some cases, for the reimbursement of debts taken out previously. The producers with greater margin to maneuver reinvested a part of the earnings in the crop (chemical pesticides, fences to protect the plantation), and in other productive areas; for example, the purchase of merchandise to resell in their small businesses. 
anteriormente. Las productoras con más margen de maniobra reinvirtieron una parte de las ganancias en el cultivo (plaguicidas químicos, cercas para proteger el huerto) y en otros rubros productivos; por ejemplo, la compra de mercancías para revender en sus pequeños negocios.

Aparte del impacto que tuvo en la economía familiar, la stevia significó también cambios en la organización de los ritmos de vida, como lo explican las productoras. Por sus características, el cultivo implica una inversión de tiempo diario importante: se debe regar la planta una o dos veces al día, podarla, quitar los botones florales, y aplicar plaguicidas y abonos a la planta cada ocho y quince días. Cada tres meses el trabajo es más intenso porque se junta el corte con el proceso de secado. Las plantas se trenzan en lazos y se tienden al sol o en un lugar cubierto. Posteriormente se despica (deshoja) y las hojas sueltas se tienden en lonas para su última fase de secado. Finalmente se empacan las hojas secas en bolsas de plástico de $8 \mathrm{~kg}$.

En varios casos otros miembros del hogar se van involucrando en las labores. Los hombres apoyan en las tareas más pesadas cuando no salen a trabajar o por las tardes: preparan los tablones para la siembra, riegan plaguicidas químicos y abonos, y cortan, entre otras cosas. Los niños y los ancianos se dedican a despicar, secar y trenzar. Las mujeres logran combinar el cultivo con las actividades del hogar y las complementarias, como las ventas por catálogo o la fabricación de manualidades, que también se realizan en casa. La posibilidad de combinar el nuevo cultivo con otras actividades es facilitada por la división del trabajo entre los miembros del hogar, la cercanía de los huertos con las viviendas y poder dedicarles tiempo en ratos libres, varias veces al día.

A nivel del paisaje y del territorio el impacto del cultivo es todavía moderado: la superficie total alcanzaba aproximadamente 40 ha en la región de San Andrés Tuxtla en septiembre de $2015^{28}$. Sin embargo, la superficie creció muy rápidamente entre enero -cuando había menos de 10 ha- y septiembre de 2015. Hubo algunos casos de expansión en parcelas ejidales, cuando el acceso al agua lo permitió. PC empezó el cultivo en agosto de 2014, con mil plantas entregadas por el programa Prospera, que sembró en una parte de su parcela colindante con el poblado. Aprovechó su conocimiento del campo, en especial del cultivo del tabaco, y agrandó su huerto de manera progresiva con plantas que otros habitantes
Apart from the impact that it had on the family economy, stevia also meant changes in the organization of life rhythms, as the producers explain. Because of its characteristics, the crop implies an important investment of daily time: the plant must be watered once or twice a day, pruned, the flower buttons removed, and pesticides and fertilizers applied to the plant every eight or fifteen days. Every three months the work is more intensive because the cutting and drying processes take place at the same time. The plants are braided into bows and laid out in the sun or a covered place. Later they are defoliated and the loose leaves are stretched out on canvases for their last phase of drying. Finally the dry leaves are packed in $8 \mathrm{~kg}$ plastic bags.

In many cases other members of the household are involved in the tasks. Men support in the heavier tasks when they do not go out to work or in the afternoons: they prepare the boards for sowing, irrigate with chemical pesticides and fertilizers, and cut, among other things. The children and elderly are devoted to defoliating, drying and braiding. The women manage to combine the cultivation with household activities and the complementary ones, such as catalog sales or handcraft manufacture, which are also carried out at home. The possibility of combining the new crop with other activities is facilitated through the division of labor between members of the households, the nearness of the plantations to the households, and being able to devote time to them during free time, many times a day.

At the level of landscape and territory, the impact of the crop is still moderate: the total surface reached approximately 40 ha in the San Andrés Tuxtla region in September $2015^{28}$. However, the surface increased quite rapidly between January - when there was less than 10 ha - and September 2015. There were some cases of expansion in ejido plots, when access to water allowed it. PC began to cultivate in August 2014, with one thousand plants delivered by the Prospera program, which she planted in a part of her plot adjoining the town. She took advantage of her knowledge of the country, especially of the tobacco crop, and enlarged her plantation progressively with plants that other inhabitants of the town gifted her for lack of space and later with others, which she reproduced herself by cuttings. In March 2015, her plantation included more than 6000 plants. By 
del pueblo le regalaron por falta de espacio y posteriormente con otras, que reprodujo él mismo por esqueje. En marzo de 2015 su huerto incluía más de 6000 plantas. Para septiembre había agrandado aún más la superficie del plantío dentro de la parcela y un huerto de traspatio, con un total aproximado de 10 000 plantas. Sin embargo, más que a estos casos aislados de expansión en parcelas, el impacto en paisaje se debió a la multiplicación de los huertos en terrenos baldíos, traspatios y en los alrededores de las casas en decenas de localidades. Esta "colonización hormiga" de las hojas verdes de la stevia marcó de manera sutil, pero persistente el paisaje rural de la región.

\section{Las incongruencias y deficiencias del proyecto, sus razones y consecuencias. Un proyecto productivo sin interés real por la producción}

En los meses que siguieron a la implicación de Prospera a nivel federal en el proyecto se decidió suplir los ingenieros agrónomos de Rayca que trabajaban con las productoras desde el inicio del proyecto, por ingenieros ambientales capacitados por los anteriores, pero sin formación agronómica. Su apoyo fue insuficiente, ya que no aumentó su número al mismo ritmo que el de los huertos. Prospera empezó a circular un pequeño manual con explicaciones sobre las distintas fases del cultivo, las labores a desarrollar y las maneras de erradicar las plagas más comunes (coleópteros, pulgones, enfermedades producidas por hongos) mediante la aplicación de licuados caseros (elaborados con verduras y especias). En una cultura esencialmente oral, las productoras no consultaron el manual; siguió circulando la información de vocales a titulares y entre las productoras, a veces de distintas comunidades. Los remedios propuestos no fueron tan efectivos y las productoras, cada vez más numerosas, se sintieron desamparadas frente a la degradación de sus plantas. Por falta de conocimientos y de asesoría, varias productoras empezaron entonces a aplicar los plaguicidas químicos que se utilizaban en el cultivo del tabaco, sin tomar en cuenta las implicaciones para las hojas de stevia ${ }^{29}$. A pesar de que el producto obtenido carecía de calidad y que la empresa Rayca no tenía necesidad de las hojas, siguió asegurando la compra. En efecto, las ventas de los productos elaborados por Rayca -cosméticos, bolsitas de té de stevia y malteada de soya en polvo llamada Sochoc- no subieron de manera significativa, a pesar de que Prospera animaba a
September she had increased even more the surface of the plantation within the plot and a backyard garden, with a total of approximately $10 \quad 000$ plants. However, more than these isolated cases of expansion in plots, the impact on the landscape was due to the multiplication of the plantations in barren lands, backyards and around the houses in dozens of localities. This "ant colonization" of the green stevia leaves marked the rural landscape of the region subtly, but persistently.

\section{Contradictions and deficiencies of the project, their causes and consequences; a productive project without real interest for production}

During the months that followed the involvement of Prospera at the federal level in the project, it was decided to replace the agronomist engineers from Rayca who worked with the producers since the beginning of the project, with environmental engineers trained by them, but without agronomic information. Their support was insufficient, since their number didn't increase at the same rhythm than that of the plantations. Prospera began to share a small manual with explanations about the different phases of the crop, the tasks to be performed, and the ways of eradicating the most common pests (coleopterans, aphids, diseases produced by fungi) through the application of home-made blends (made with vegetables and spices). In an essentially oral culture, the producers did not consult the manual; the information continued to circulate from vocals to title holders and among producers, sometimes from different communities. The remedies proposed were not as effective and the producers, increasingly more numerous, felt helpless in face of the degradation of their plants. Because of lack of knowledge and assistance, several producers began then to apply the chemical pesticides that were used in tobacco cultivation, without taking into account the implications for the stevia leaves ${ }^{29}$. Despite the product obtained lacking quality and the Rayca company not having the need for leaves, it continued to ensure the purchase. In fact, the sales of products elaborated by Rayca - cosmetics, stevia tea bags and powdered soy milkshakes called Sochoc - did not increase significantly, despite Prospera encouraging the producers to purchase the latter product (which is sold in the Liconsa stores ${ }^{30}$ ) to promote the crop. 
las productoras a comprar el último producto (que se vende en las tiendas Licons $\mathrm{a}^{30}$ ) para incentivar el cultivo. Por otra parte, la empresa no encontró la manera de procesar la hoja para obtener un endulzante estándar $^{31}$. Por lo tanto, la demanda de hojas no creció y la empresa incluso se habría podido surtir solamente con las obtenidas en sus propios plantíos. A pesar de esto, frente al aumento de la cantidad de hojas cosechadas como consecuencia de la expansión de los huertos, Rayca siguió comprando hojas durante los primeros meses de 2015 , a un precio de $\$ 350.00$ por kilo, sobrevalorado en relación con el precio mundial (véase nota 22).

Durante estos meses y hasta la actualidad, hubo poca información fidedigna por parte de la SEDESOL o de la empresa sobre el cultivo, las labores y las ventas. Las productoras ignoraban si el comprador era SEDESOL, Rayca u otra empresa; desconocían el destino y el proceso de la hoja; se confundían entre los asesores y sus empleadores. Se rumoreaba además información diversa y contradictoria sobre los precios, el tipo de pago, las fechas de recolección y los supuestos privilegios de las productoras de las localidades vecinas y de las vocales.

\section{Un fin electoral}

Las numerosas incongruencias del programa y los testimonios de los productores permiten relacionar este proyecto con el uso de los programas sociales para fines político-electorales, que tiene una larga tradición en México y está referido por distintos autores (Vilalta, 2007; Hevia, 2010; Bey y Combes, 2011). La captura de proyectos y fondos por parte de líderes locales, sobre todo en épocas electorales, ha sido reportada como persistente en programas de transferencias condicionadas como Prospera, Procampo y Liconsa, a pesar de que se ha buscado establecer candados, tanto en los términos de referencia como en las formas de operación, con el fin de evitar su utilización con propósitos electorales. Sin embargo, no se ha logrado frenar el corporativismo y el clientelismo político, prácticas más comunes en la población beneficiaria de programas que en la no beneficiaria (Vilalta, 2007). Si en los últimos años se han comprobado menos casos de coacción (amenazas, condicionamiento de los apoyos, violencia), las prácticas clientelares y semiclientelares se han multiplicado, adoptando formas variadas y complejas (Hevia, 2010).
On the other hand, the company didn't find the way to process the leaf to obtain a standard sweetener ${ }^{31}$. Therefore, the demand for leaves did not grow and the company could have even been stocked solely with the ones obtained in its own plantations. Despite this, in face of the increase of leaves harvested as consequence of the expansion of plantations, Rayca continued to purchase leaves during the first months of 2015, at a price of $\$ 350.00$ per kilogram, overvalued with regards to the world price (see note 22).

During these months and up until now, there was little reliable information from SEDESOL or the company about the crop, the tasks and the sales. The producers ignored whether the buyer was SEDESOL, Rayca or another company; they ignored the destination and process of the leaf; they were confused by the advisers and their employers. In addition, there were rumors of diverse and contradictory information about the prices, the type of payment, the dates of collection, and the supposed privileges of producers from the neighboring localities and the vocals.

\section{An electoral objective}

The many contradictions of the program and the testimonies from the producers allow relating this project with the use of social programs for politicalelectoral purposes, which has a long tradition in México and has been described by different authors (Vilalta, 2007; Hevia, 2010; Bey and Combes, 2011). The capture of projects and funds by local leaders, particularly in electoral times, has been reported as persistent in programs of conditioned transfers like Prospera, Procampo and Liconsa, even when it has been sought to establish locks, both in terms of reference and in the manners of operation, with the aim of preventing their use with electoral purposes. However, political corporativism and cronyism have not been stopped, which are more common practices in the population of program beneficiaries than in non-beneficiaries (Vilalta, 2007). If in recent years less cases of coaction have been proven (threats, conditioning backing, violence), the clientele and semi-clientele practices have been multiplied, adopting varied and complex forms (Hevia, 2010). On several occasions, the Prospera program has been accused of doing proselytism, especially through its program "National Crusade against Hunger"32. 
En varias ocasiones el programa Prospera ha sido acusado de hacer proselitismo, en especial mediante su programa "Cruzada Nacional contra el Hambre" 32.

En el caso de la stevia, el trabajo de campo permitió establecer una relación entre el proyecto de cultivo y el proceso electoral del 7 de junio de 2015. Ese día se eligieron 500 diputados federales (así como gobernadores, presidentes municipales y diputados locales en varios estados). En el Distrito de San Andrés Tuxtla del estado de Veracruz, uno de los candidatos fue Jorge Carvallo Delfín, que poco antes había sido delegado estatal de la SEDESOL.

Si retomamos una por una las incongruencias del programa (rápida expansión de un cultivo sin que exista una demanda correspondiente; compra de toneladas de hojas de mala calidad sin que haya mercado y precio sobrevalorado; sustitución de asesores calificados por otros menos aptos; falta de información y secretismo), dan indicaciones sobre el objetivo real: aportar beneficios económicos a las titulares de Prospera para convencerlas de que el Gobierno en turno les estaba apoyando e influenciar así su voto. Lo que importaba era multiplicar el número de beneficiarias de los huertos y pagar a buen precio las primeras entregas para suscitar el interés y el entusiasmo de las productoras. Esto fue permitido por el apoyo económico del empresario de Rayca, que se alió al proyecto motivado por pretensiones políticas. El precio sobrevalorado de la hoja de stevia fue fijado por la empresa de manera aleatoria, sin relación con el mercado mundial ni con la demanda. La calidad de las hojas y al uso de productos químicos no fueron temas de preocupación, ya que al no ser un proyecto productivo real, ni la producción, ni la calidad del producto importaban.

El desconocimiento, la confusión y los mitos sobre el proceso fueron favorecidos por SEDESOLProspera para aumentar el desconocimiento y la vulnerabilidad de las productoras e imponer sus condiciones sin que pudieran cuestionarlas ni organizarse, aplicando un "mecanismo de control social sobre los votantes" (Vilalta, 2007, 36). De la misma manera, el papel otorgado a las vocales, más informadas y a menudo favorecidas económicamente por el proyecto, permitió tenerlas "ganadas a la causa". Estas intermediarias -que tienen un papel esencial en el buen funcionamiento del programa Prospera, demostrado por Felipe Hevia (2010) - fueron quienes calmaron los ánimos, desarmaron los conflictos y las quejas, y defendieron el proyecto, a pesar de sus inconsistencias,
In the case of stevia, the field work allowed establishing a relationship between the cultivation project and the electoral process of June $7^{\text {th }}, 2015$. That day 500 federal representatives were elected (as well as governors, municipal presidents and local representatives in several states). In the District of San Andrés Tuxtla of the state of Veracruz, one of the candidates was Jorge Carvallo Delfín, who shortly before had been SEDESOL state delegate.

If we take up again one by one the contradictions of the program (fast expansion of a crop without there being a corresponding demand; purchase of tons of low quality leaves without there being a market, and overvalued price; substitution of qualified advisers for other less apt ones; lack of information and secrecy), these provide indications about the real objective: to contribute economic benefits to the Prospera title holders to convince them that the government in office was supporting them and thus influencing their vote. What mattered was multiplying the number of beneficiaries of the plantations and paying the first deliveries at a good price to arouse the interest and enthusiasm of the producers. This was allowed by the economic support of the Rayca businessman, who was allied to the project motivated by political aspirations. The overvalued price of the stevia leaf was fixed by the company randomly, without relation to the global market or to the demand. The quality of the leaves and the use of chemical products were not issues to be worried about, since because it was not a true productive project, neither the production nor the quality of the product mattered.

The lack of knowledge, the confusion and the myths about the process were favored by SEDESOLProspera to increase the ignorance and vulnerability of the producers and to impose their conditions without them being questioned or the women being able to organize themselves, applying a "mechanism of social control on the voters" (Vilalta, 2007, 36). In the same way, the role given to the vocals, the most informed and often economically favored by the project, allowed having them "won over to the cause". These intermediaries - who have an essential role in the proper functioning of the Prospera program, as shown by Felipe Hevia (2010) - were the ones who calmed the waters, defused conflicts and complaints, and defended the project, despite its inconsistencies, delays and defaults. The new field advisers were other intermediaries, who were hired, according to the 
tardanzas e incumplimientos. Los nuevos asesores de campo fueron otros intermediarios, quienes según los testimonios recolectados fueron contratados para evidenciar los beneficios y las bondades que representó la stevia para las productoras y relacionarlos con el nombre del candidato a la diputación o con el del PRI ${ }^{33}$. Las productoras entrevistadas que cobraron en diciembre de 2014 la cantidad de $\$ 1000$ por kilo de hoja seca comentaron que estos asesores explicaron que la empresa dio $\$ 350.00$ por kilo y que "el Presidente de la República” proporcionó $\$ 750.00$ complementario. Fue una manera muy clara de señalar quién les apoyaba y de indicarles "cómo votar bien" en las siguientes elecciones, de manera a que siga el apoyo. La visita a Salto de Eyipantla de la titular de la SEDESOL a nivel federal, Rosario Robles Berlanga, acompañada por el Gobernador del Estado de Veracruz Javier Duarte Ochoa, el 14 de enero 2015, seguida por la del Presidente de la República un mes más tarde (16 febrero), constituyen otros apoyos fuertes otorgados al cultivo de la stevia y a través de él, al candidato del PRI del distrito de San Andrés Tuxtla.

El 7 de junio, Jorge Carvallo Delfín ganó la diputación federal con $50.92 \%$ de los votos ${ }^{34}$ aunque, como lo menciona Combes (2011), los bienes y favores no garantizan el apoyo y la lealtad de los "clientes" y no se puede comprobar de manera formal y estadística que esta victoria se debió a los votos de las beneficiarias de Prospera, el intento de capturar la confianza de las productoras, orientar el voto y crear así una dinámica clientelar está comprobado ${ }^{35}$.

En Los Tuxtlas, esta "captura" por operadores políticos o por caciques tradicionales se fundamenta en el recambio y refuncionalización de liderazgos que ha ocurrido en la región, asociados a lo que Léonard (2003) denomina como la territorialización de las redes sociales a nivel local. Diversos proyectos de desarrollo e iniciativas promovidos en la zona por parte de instituciones académicas, OSC, iglesias y agencias internacionales han enfrentado estas mismas dificultades durante varias décadas (Paré, 1996; Casados, 2008; Paré y Robles, 2005; Cruz Ramírez y Tehuitzil Valencia, 2009; Piñar Álvarez et al., 2012).

\section{La situación post-electoral}

En los dos meses anteriores a las elecciones, los representantes de SEDESOL-Prospera tuvieron que respetar la veda electoral y no acudieron a la región: testimonies collected, to evidence the benefits and qualities that stevia represented for the producers and to relate them to the name of the candidate to the deputation or the PRI candidate ${ }^{33}$. The producers interviewed who charged in December 2014 the amount of $\$ 1000$ per kilogram of dry leaf mentioned that these advisers explained that the company gave $\$ 350.00$ per kilogram and that "the President of the Republic" provided $\$ 750.00$ complementary. It was a very clear way of signaling who was supporting them and of indicating "how to vote right" in the next elections, in order for the support to continue. The visit to Salto de Eyipantla of the director of the SEDESOL at the federal level, Rosario Robles Berlanga, accompanied by the governor of the state of Veracruz, Javier Duarte Ochoa, on January $14^{\text {th }} 2015$, followed by that of the President of the Republic one month later (February $16^{\text {th }}$ ), constitute other strong supports given to the stevia crop and through this, to the candidate of the PRI from the district of San Andrés Tuxtla.

On June $7^{\text {th }}$, Jorge Carvallo Delfín won the federal deputation with $50.92 \%$ of the votes ${ }^{34}$, and although, as Combes (2011) mentions, the goods and favors did not guarantee the support and loyalty of the "clients" and it cannot be proven formally and statistically that this victory was due to the votes from the Prospera beneficiaries, the attempt to capture the trust of the producers, direct the vote and thus create a clientele dynamic is proven ${ }^{35}$.

In Los Tuxtlas, this "capture" by political operators or by traditional overlords is based on the replacement and refunctionalization of leadership that has taken place in the region, associated to what Léonard (2003) names as the territorialization of social networks at the local level. Various development projects and initiatives promoted in the zone by academic institutions, NGOs, churches and international agencies have faced these same difficulties for several decades (Paré, 1996; Casados, 2008; Paré and Robles, 2005; Cruz Ramírez and Tehuitzil Valencia, 2009; Piñar Álvarez et al., 2012).

\section{The post-electoral situation}

In the two months prior to the elections, representatives from SEDESOL-Prospera had to respect the electoral ban and did not go to the region: advice was given over the telephone and the 
las asesorías se hicieron por teléfono y las productoras sabían que durante estos meses no iba a haber recolección de hojas. La incógnita era si se iban a reanudar las compras después de las elecciones y sobre la permanencia del cultivo.

Al final del mes de junio 2015 los representantes de Prospera finalmente regresaron, pero no a todas las localidades, ni para comprar la totalidad de la producción. En Matacapan las productoras habían cortado dos veces después de la siembra de febrero, pero hasta septiembre nadie había pasado a recolectar las bolsas; después de seis meses de labores, pequeñas inversiones y esfuerzo, no habían cobrado ni un peso. En la localidad de Bezuapan, la hoja fue colectada y pagada a 25 productoras y, como se habían juntado dos cosechas por la veda eletoral, las ganancias fueron importantes. Por ejemplo, PC obtuvo 73 kilos de las dos cosechas y ganó $\$ 17500.00$, pero a 15 productoras de la misma localidad no se les compró la hoja, sin explicaciones, lo que ocasionó incomprensión y desesperación.

Otra novedad post-electoral fue que se aplicaron precios diferenciados al producto, de $\$ 150.00$ a $\$ 350.00$ por kg de hoja, aducido a un control de calidad (las bolsas con hojas color negro o café se pagaban menos que las bolsas con hojas verdes). Esto pudo ser una manera aleatoria de reducir los costos para Prospera. La incertidumbre de las ventas y el precio variado e inferior a lo que se esperaba ${ }^{36}$, además del desfase entre las horas y esfuerzos que las productoras dedicaron al huerto y las ganancias obtenidas, provocaron un desanimo generalizado. Algunas arrancaron las plantas; otras abandonaron sus huertos o le dieron solamente unos cuidados mínimos, con lo que el plantío creció sin control y se enmalezó.

El cultivo permaneció porque la SEDESOL siguió trabajando con la stevia por no mostrar versatilidad ni hacer evidente la manipulación preelectoral en cuanto a un proyecto que había sido apoyado por el Presidente de la República en persona. Era importante seguir con las nuevas reglas de operación y el proyecto de inclusión productiva. Sin embargo, la ausencia de mercado para la hoja se presentó más fuerte que nunca porque, por desacuerdos políticos posteriores a las elecciones, el empresario de Rayca se desvinculó del proyecto y dejó de comprar la hoja. Si en los meses posteriores a las elecciones SEDESOLProspera no recolectó la stevia de manera sistemática, fue porque estuvo rebasada por la cantidad de hojas producers knew that during those months there was not going to be leaf collection. The question was whether the purchases would be renewed after the elections and about the permanence of the crop.

At the end of the month of June, 2015, the representatives of Prospera finally returned, but not to all the localities, or to purchase the totality of the production. In Matacapan the producers had cut twice after the sowing in February, but until September no one had visited to collect the bags; after six months of tasks, small investments and effort, they had not charged even one peso. In the locality of Bezuapan, the leaf was collected and paid to 25 producers and, since two harvests had added up due to the electoral ban, the earnings were important. For example, PC obtained 73 kilos from the two harvests and earned $\$ 17500.00$, but no leaf was bought from 15 producers from the same locality, without explanation, which caused incomprehension and desperation.

Another post-electoral novelty was that differentiated prices were applied to the product, from $\$ 150.00$ to $\$ 350.00$ per $\mathrm{kg}$ of leaf, adduced to quality control (the bags with black or brown colored leafs were paid less than the bags with green leaves). This could be a random way of reducing the costs for Prospera. The uncertainty of the sales and the varied and lower price than was expected ${ }^{36}$, in addition to the discrepancy between the hours and efforts that the producers devoted to the plantation and the earnings obtained, caused generalized despondency. Some pulled out the plants; others abandoned their plantations or gave them only minimal care, with which the plantation grew without control and became weedy.

The crop remained because SEDESOL continued working with stevia as a result of not showing versatility or making evident the pre-electoral manipulation in terms of a project that had been supported by the President of the Republic in person. It was important to continue with the new rules of operation and the project of productive inclusion. However, the absence of market for the leaf was stronger than ever because, due to political disagreements previous to the elections, the Rayca businessman disassociated himself from the project and ceased to purchase the leaf. If in the months after the elections SEDESOLProspera did not collect the stevia systematically, it was because it was overwhelmed by the amount of 
obtenidas. No había posibilidad de venderlas a grandes grupos, como FEMSA o Bimbo, a pesar de la demanda creciente, porque la hoja no pasaría los filtros de calidad. En septiembre 2015 se hablaba del involucramiento de otra empresa, con más capacidad de inversión que Rayca, que podría comprar la hoja, procesarla y fabricar nuevos productos derivados, como miel de stevia. La situación seguía siendo de incertidumbre por la falta de un esquema productivo sólido.

\section{Conclusión}

La manera en que fue operado el proyecto de los huertos de stevia en las localidades de estudio muestra evidencias de que el objetivo del mismo era intentar "llevar a los votantes a escoger el buen candidato" (Bey y Combes, 2011). Esta aseveración se basa en las múltiples fallas que se observan en su instrumentación y en las entrevistas que se realizaron. Adicionalmente, pudieron reconocerse otros "efectos colaterales negativos" en esta iniciativa, como la obtención de beneficios desiguales y limitados para las productoras, con mejores beneficios para las vocales en comparación con las otras titulares, por ejemplo, lo que acentuó las desigualdades a nivel local. Mientras tanto, los actores políticos continuaron promocionando mediáticamente al proyecto como una iniciativa "gana-gana", cuando el logro parecía ser mucho más significativo para ellos que para las productoras.

Esta experiencia muestra una vez más la desviación que pueden encerrar las políticas de combate a la pobreza en contextos con una arraigada tradición clientelar cuando se deja de lado las posibilidades de reactivar efectivamente las economías locales y con esto ampliar las oportunidades de los hogares más desfavorecidos.

\section{Notas}

${ }^{1}$ Entrevistas realizadas entre enero y septiembre del año 2015. Interviews carried out between January and September, 2015.

${ }^{2}$ Dicho programa funciona con base en apoyos monetarios destinados a mejorar la alimentación, a la promoción de la salud y al favorecimiento de una mayor cobertura educativa (Diario Oficial, 2014). * This program functions based on monetary backing destined to improving the diet, promoting health, leaves obtained. There was no possibility of selling them to large groups, such as FEMSA or Bimbo, despite the growing demand, because the leaf would not pass the quality filters. In September 2015 there was talk of the participation of another company, with greater investment capacity than Rayca, which could purchase the leaf, process it and manufacture new byproducts, such as stevia honey. The situation continued to be of uncertainty from the lack of a solid productive scheme.

\section{Conclusion}

The manner in which the project of stevia plantations was operated in the localities of study shows evidence that its objective was to attempt "to lead the voters to choose the right candidate" (Bey and Combes, 2011). This assertion is based on the multiple faults that were observed in its implementation and on the interviews performed. In addition, other "negative collateral effects" could be recognized in this initiative, such as obtaining unequal and limited benefits for the producers, with better benefits for the vocals in comparison to the other title holders, for example, which accentuated the inequalities at the local level. Meanwhile, the political actors continued to promote in the media the project as a "win-win" initiative, when the achievement seemed to be much more significant for them than for the producers.

This experience shows once more the deviation that policies used to combat poverty can have within contexts with a rooted clientele tradition, when the possibilities of effectively reactivating the local economies and with it broaden the opportunities of the most disadvantaged households, are put aside.

$$
\text { - End of the English version - }
$$

and favoring a better educational coverage (Diario Oficial, 2014).

${ }^{3}$ DFID, Department for International Development. 1999. Livelihoods Guidance Sheets: http://www. livelihoods.org. * DFID, Department for International Development. 1999. Livelihoods Guidance Sheets: http://www.livelihoods.org

${ }^{4}$ Estimaciones de la compañía Canadean, dedicada 
a estudios de mercado a nivel internacional: http:// www.canadean.com/news/rising-demand-for-natural-sweeteners. Estimations from the Canadean Company, devoted to international market studies: http://www.canadean.com/news/rising-demand-fornatural-sweeteners

${ }^{5}$ Estos nuevos endulzantes se clasifican por su origen y aporte energético en: naturales y artificiales, calóricos y no calóricos. These new sweeteners are classified from their origin and energetic contribution into: natural and artificial, caloric and non-caloric. ${ }^{6}$ USDA, United State Department of Agriculture-Foreign Agricultural Service. Información actualizada hasta 5/25/2016: http://www.ers.usda.gov/data-products/sugar-and-sweeteners-yearbook-tables.aspx6. * USDA, United State Department of AgricultureForeign Agricultural Service. Información actualizada hasta 5/25/2016: http://www.ers.usda.gov/dataproducts/sugar-and-sweeteners-yearbook-tables. aspx6

${ }^{7}$ ISO, International Sugar Organization: http://www. isosugar.org/ * ISO, International Sugar Organization: http://www.isosugar.org.

${ }^{8}$ Global Industry Analysts. INC. 2016: http://www. strategy.com/Artificial_Sweeteners_Market_Report. asp * Global Industry Analysts. INC. 2016: http:// www.strategy.com/Artificial_Sweeteners_Market_ Report. asp.

${ }^{9}$ Nestlé, Cargill Inc, PureCircle Ltd., Stevia Corp., EvolvaHolding S.A., Coca Cola, PepsiCo Inc., Tate \& Lyle Plc. y GLG Life Tech Corp. * Nestlé, Cargill Inc, PureCircle Ltd., Stevia Corp., EvolvaHolding S.A., Coca Cola, PepsiCo Inc., Tate \& Lyle Plc. and GLG Life Tech Corp.

${ }^{10} \mathrm{Se}$ le han atribuido propiedades estimulantes de la producción de insulina, así como capacidad para reducir la hipertensión y funcionar como agente antibacteriano e inmunomodulador (Salvador et al., 2014). Stimulating properties have been attributed from insulin production, as well as capacity to reduce hypertension and function as antibacterial and immune-modulating agent (Salvador et al., 2014).

${ }^{11}$ Food Business News: http://www.foodbusinessnews.net/ * Food Business News: http://www. foodbusinessnews.net/

${ }^{12}$ Mintel: http://www.mintel.com/press-centre/foodand-drink/stevia-set-to-steal-intense-sweetener-market-share-by-2017-reports-mintel-and-leatherheadfood-research * Mintel: http://www.mintel.com/ press-centre/food-and-drink/stevia-set-to-steal-intense-sweetener-market-share-by-2017-reports-mintel-and-leatherhead-food-research

${ }^{13}$ ZAFRANET. Comunicaciones con datos de USDA y BEVERAGE DIGEST. 2015: http://www.zafranet. $\mathrm{com} /$ ZAFRANET. Communications with USDA and BEVERAGE DIGEST data. 2015: http://www. zafranet.com/

${ }^{14}$ Este es el caso de Ley del Impuesto Especial sobre Producción y Servicios (IEPS), que estableció un gravamen de $\$ 1.00$ por litro a las bebidas saborizadas y azucaradas, emitido el 8 de septiembre de 2013. * This is the case of the Law of Special Tax on Production and Services (Ley del Impuesto Especial sobre Producción y Servicios, IEPS), which established a tax of $\$ 1.00$ per liter on flavored and sugared beverages, emitted on September $8^{\text {th }}, 2013$.

${ }^{15} \mathrm{El}$ número de productos que la incluyen como endulzante en América Latina registró en 2014 un crecimiento del $45 \%$ respecto del ańo anterior. Revista Énfasis con datos de Global Stevia Institute: http://www.alimentacion.enfasis.com * The number of products that include it as a sweetener in Latin America showed a growth of $45 \%$ in 2014 compared to the prior year. Revista Énfasis with data from Global Stevia Institute: http://www.alimentacion. enfasis.com.

${ }^{16}$ Grupo Pegaso de la familia Azcárraga, dueños de Televisa y Movistar, entre otras compañías. Stevia Maya: http://www.steviamaya.com/empresa.php * Grupo Pegaso from the Azcárraga family, owners of Televisa and Movistar, among other companies. Stevia Maya: http://www.steviamaya.com/empresa.php ${ }^{17} \mathrm{La}$ información proporcionada en este capítulo proviene en su mayor parte de entrevistas realizadas a los productores y a responsables del proyecto a distintos niveles (ingenieros, delegado estatal de Próspera). No existe información documental sobre el tema, excepto algunos artículos de periódicos locales. The information provided in this chapter comes mostly from interviews carried out with producers and those responsible for the project at different levels (engineers, Prospera state delegate). There is no documental information about the theme, except some articles from local newspapers.

${ }^{18}$ Entrevista el 27 de enero de 2015. Interview from January $27^{\text {th }}, 2015$.

${ }^{19}$ Según este documento, el programa debía funcionar con tres componentes -alimentación, salud, 
educación- y seguir cuatro líneas de acción: inclusión productiva, inclusión laboral, inclusión financiera e inclusión social (Prospera). According to this document, the program should function with three components - diet, health, education - and follow four lines of action: productive inclusion, labor inclusion, financial inclusion, and social inclusion (Prospera).

${ }^{20}$ Como la stevia es una planta de ciclo corto, los químicos utilizados se quedan en las hojas, por lo cual es deseable el uso exclusivo de productos orgánicos. - Since stevia is a plant of short cycle the chemicals used stay on the leaves, which is why the exclusive use of organic products is desirable.

${ }^{21}$ Hubo más titulares interesadas, pero no todas pudieron cumplir con los requisitos. There were more owners interested, but not all of them could comply with the requirements.

${ }^{22}$ El precio está sobrevaluado, y lo es todavía con un precio de venta de 350 pesos por $\mathrm{kg}$, ya que el precio de la estevia a nivel mundial a inicios de 2015 era de nueve dólares por kilo. The price is overvalued, and it still is with a sales price of 350 pesos per $\mathrm{kg}$, since the global price of stevia at the beginning or 2015 was nine dollars per kilo.

${ }^{23}$ Declaración pública de Rosario Robles Berlanga, titular de SEDESOL, ante los productores durante una visita a San Andrés Tuxtla, publicada en distintos medios de comunicación locales. Ver por ejemplo Periódico de San Andrés, 8 de agosto 2014, http://periodicodesanandres. blogspot.mx/2014/08/se-planea-feria-internacional-dela.html Public declaration by Rosario Robles Berlanga, head of SEDESOL, in face of the producers during a visit to San Andrés Tuxtla, published in different local media. See for example Periódico de San Andrés, August $8^{\text {th }}$, 2014, http://periodicodesanandres.blogspot.mx/2014/08/seplanea-feria-internacional-de-la.html.

${ }^{24} \mathrm{La}$ implantación de un huerto está evaluada en 13000 pesos. The implantation of a plantation is valued at 13000 pesos.

${ }^{25}$ Las productoras no sabían que hay que evitar la floración de la planta, quitando los botones florales a medida que van creciendo, para que no se debilite la planta. The producers didn't know they had to avoid the plant's flowering, taking off the flower buttons as they grow, so the plant does not weaken.

${ }^{26} \mathrm{AR}$ ha trabajado en un proyecto para componer la red eléctrica del pueblo, con un sueldo de 180 pesos diarios, y ha trenzando tabaco en una bodega por 200 pesos diarios. Son sueldos superiores a lo que gana normalmente un peón en el campo (120 pesos).

AR has worked on a project to fix the town's electrical network, with a salary of 180 pesos per day, and has braided tobacco in a storehouse for 200 pesos daily. These are higher wages than what a day laborer earns normally in the field (120 pesos).

${ }^{27}$ Las familias tienen derecho al Seguro Popular, que presenta múltiples deficiencias, en especial la falta de medicinas. The families have the right to the Seguro Popular, which presents multiple deficiencies, especially the lack of medicines.

${ }^{28}$ Corresponde a los 4000 huertos implantados por SEDESOL en el municipio de San Andrés Tuxtla y alrededores, y a los plantíos de la empresa Rayca (6.5 ha). En comparación, la superficie sembrada de tabaco en el municipio de San Andrés Tuxtla es de 602 ha. This corresponds to the 4000 plantations implanted by SEDESOL, in the municipality of San Andrés Tuxtla and outskirts, and to the plantations of the Rayca company (6.5 ha). In comparison, the surface sown with tobacco in the municipality of San Andrés Tuxtla is 602 ha.

${ }^{29}$ Las entrevistas permitieron constatar que muchas productoras no saben si el producto aplicado es orgánico o no. The interviews allowed confirming that many producers do not know whether the product applied is organic or not.

${ }^{30}$ Liconsa está constituida como una empresa de participación estatal mayoritaria que trabaja con el propósito de mejorar los niveles de nutrición en México. * Liconsa is constituted as a business of majority state participation that works with the purpose of improving the levels of nutrition in México.

${ }^{31}$ Es decir blanco y en polvo, parecido al azúcar refinado o a los edulcorantes sintéticos, tal como lo comercializan ya varias marcas de México (Svetia, etcétera). * That is, white and in powder, similar to refined sugar or synthetic sweeteners, just like many brands already marketed it in México (Svetia, etc.).

${ }^{32}$ Reportado por ejemplo en: http://www.jornada. unam.mx/2015/05/18/politica/003n1pol * Reported for example in: http://www.jornada.unam. $\mathrm{mx} / 2015 / 05 / 18 /$ politica/003n1 pol

${ }^{33}$ Lo que no estaban haciendo los agrónomos anteriores, enfocados en el control de las plagas y el crecimiento de las plantas. Something the previous agronomists were not doing, being focused on pest control and plant growth. 
$3434.33 \%$ del PRI, $14.85 \%$ del Partido verde, $1.74 \%$ del PRI + Partido Verde. Instituto Nacional Electoral Cómputos Distritales. Elección de diputados federales. Tabla de resultados, consultado el 19 de agosto de 2016 en: http://computos2015.ine.mx/ Entidad/DistritosPorCandidatura/detalle.html\#!/30 * 34.33 \% for PRI, $14.85 \%$ for Partido Verde, $1.74 \%$ for PRI + Partido Verde. Instituto Nacional Electoral Cómputos Distritales. Elección de diputados federales. Results, consulted on August $19^{\text {th }} 2016$ in: http://computos2015.ine.mx/Entidad/DistritosPorCandidatura/detalle.html\#!/30

${ }^{35}$ Como el objetivo inicial del trabajo es la evaluación de un nuevo proyecto productivo, no buscamos indagar más sobre estas prácticas, ni cuantificarlas. Solo señalamos su existencia y los efectos que tuvo sobre el proyecto. Since the initial objective of the study is the evaluation of a new productive project, we did not seek to inquire more about these practices, or to quantify them. We only point to their existence and the effects they had on the project.

${ }^{36}$ Muchas productoras se quedaron con el recuerdo del precio de mil pesos por $\mathrm{kg}$, pagado al final del año 2014. Many producers were left with the memory of the price of one thousand pesos per $\mathrm{kg}$, paid at the end of the year 2014 .

\section{Literatura Citada}

Auyero, Javier. 2011. Relaciones, cada día. Desacatos Revista de Antropología Social, núm.36, mayo-agosto. México.

Bey, Marguerite, y Héléne Combes. 2011. El intercambio en política. Desacatos Revista de Antropología Social, núm.36, mayo-agosto. México.

Casados González, Estela. 2008. Viviendo con el virus del papiloma humano. Marginación y desigualdades de género en la población campesina de Los Tuxtlas, Veracruz, México. Working Paper Series \#14. Observatory on Inequality in Latin America-Small Grant Recipient 2007-2008. Consultado el 5 de septiembre 2015 In: http://www.sitemason.com/files/lMZuNy/SMALL\%20 GRANTS\%202008\%20REPORTSEstelaCasados.pdf

Combes, Héléne. 2011. ¿Dónde estamos con el estudio del clientelismo? Desacatos Revista de Antropología Social, núm.36, mayo-agosto. México.

CONAPO (Consejo Nacional de Población). 2010.Índices de Marginación por Localidad. Consultado el 3 de mayo de 2015 In: http://www.conapo.gob.mx/es/CONAPO/Indices_de_Marginacion_Publicaciones

Cruz Ramírez, Susana, y Lucio Tehuitzil Valencia. 2009. Mujeres y tecnología alternativa; una experiencia en la Sierra de Santa Marta, Veracruz. En: Arturo León López, y Gisela Espinosa Damián (coords). El Desarrollo Rural desde la Mirada Local. UAM-Xochimilco- CSH, Depto. de Producción Económica. México.
Diario Oficial. 30 de diciembre de 2014. Octava Sección, Poder Ejecutivo, Secretaria de Desarrollo Social, Prospera, reglas de operación. Consultado el 1 de mayo de 2015: http://www. normateca.SEDESOL.gob.mx/work/models/NORMATECA/Normateca/Reglas_Operacion/2015/rop_prospera.pdf

Ellis, Frank. 2000. Rural Livelihoods and Diversity in Developing Countries. Oxford University Press, Oxford.

García Almeida, José Manuel, Gracia María Casado Fernández, y José García Alemán. 2013. Una visión global y actual de los edulcorantes. Aspectos de regulación. Revista Nutrición Hospitalaria, 28 (Supl.4). Málaga, España.

García Chávez, Luis Ramiro. 2011. Análisis de Mercado de los edulcorantes en México. Reporte de resultados. CONADESUCA. México.

Hevia De la Jara, Felipe. 2007. La contraloría social en el Programa Oportunidades desde una óptica de interfaz socioestatal. En: Contraloría y participación social para la gestión pública. Centro Latinoamericano de Administración para el Desarrollo. Caracas, Venezuela.

Hevia de la Jara, Felipe. 2010. Uso político de programas sociales y nuevos intermediarios institucionales: el Programa Progresa/Oportunidades en el sur de Veracruz. Desacatos Revista de Antropología Social, núm.34, septiembre-diciembre. México.

INEGI (Instituto Nacional de Estadística y Geografía). 2010. Censo de Población y Vivienda 2010. Consultado el 12 de mayo 2015 In: http://www.inegi.org.mx/est/contenidos/ proyectos/ccpv/cpv2010/

Léonard, Eric. 2003. Titularización agraria y apropiación de nuevos espacios económicos por los actores rurales: el Procede en los Tuxtlas, estado de Veracruz. In: Eric Léonard, André Quesnel, y Emilia Velázquez (coords). Políticas y regulaciones agrarias. Dinámicas de poder y juegos de actores en torno a la tenencia de la tierra. Miguel Ángel Porrúa/Ciesas/IRD. México.

Paré, Luisa. 1996. Experiencia de gestión municipal y comunitaria de los recursos naturales en el Sur de Veracruz. In: Luisa Paré, y Martha Judith Sánchez (coords). El ropaje de la tierra. Naturaleza y cultura en cinco zonas rurales. Plaza y Valdés/ IIS/UNAM. México.

Paré, Luisa, y Carlos Robles. 2005. La gestión territorial y comunitaria del agua: una experiencia de un municipio indígena en el sur de Veracruz. Mirada Antropológica, Revista del Cuerpo Académico de Antropología de la Facultad de Filosofía y Letras de la BUAP, Nueva Época, No. 4. México.

Piñar Álvarez, Ángeles, María Dolores García Segura, y Helio García Campos. 2012. Ecoturismo y educación ambiental para la sustentabilidad en la Reserva de la Biósfera de Los Tuxtlas, México. Revista TURYDES, Vol 5, Núm 12. México.

Ramírez Jaramillo, Genovevo. 2011. Programa Estratégico para el Desarrollo Rural sustentable de la Región Sur Sureste de México: Trópico Húmedo 2011. Paquete Tecnológico Estevia (Stevia rebaudania). Establecimiento y mantenimiento. Gobierno Federal, Sagarpa, INIFAP. México.

SAGARPA (Secretaria de Agricultura, Ganadería, Desarrollo Rural, Pesca y Alimentación). 2013. Publicado el 31 de octubre de 2013, consultado el 1 de mayo de 2015 en: http:// www.sagarpa.gob.mx/delegaciones/Campeche/boletines/ Paginas/2013B061.aspx 
Salvador-Reyes, Rebeca, Medaly Sotelo-Herrera, y Luz PaucarMenacho. 2014. Estudio de la Stevia (Stevia rebaudiana Bertoni) como edulcorante natural y su uso en beneficio de la salud. Scientia Agropecuaria, vol.5, no.3. Universidad Nacional de Trujillo, Perú.

Scoones, Ian. 1998. Sustainable Rural Livelihoods: A framework for Analysis. Institute of Development Studies. Brighton, Inglaterra.

Secretaria de Economía, Dirección General de Industrias Básicas. 2012. Análisis de la situación económica, tecnológica y de política comercial del sector edulcorantes en México. Consultado el 12 de marzo 2015 en: http://www.economia.gob.mx/files/comunidad_negocios/industria_comercio/Analisis_Sectorial_Mercado_Edulcorantes. pdf

SIAP (Servicio de Información Agroalimentaria y Pesquera). 2014. Cierre de la producción agrícola por cultivo. Consultado el 5 de enero de 2015 In: http://www.siap.gob.mx/ cierre-de-la-produccion-agricola-por-cultivo/

Vilalta Perdomo, Carlos J. 2007. Compra y coacción del voto en México. Variaciones estatales y diferencias de opinión entre beneficiarios y no beneficiarios de programas sociales. Serie ENAPP, Documento de trabajo $n^{\circ} 4$, Programa de las Naciones Unidas para el Desarrollo. México. 